\title{
Procurement and mobility during the Late Pleistocene: Characterising the stone-tool assemblage of the Picamoixons site (Tarragona, NE Iberian Peninsula)
}

\author{
María Soto \\ Institut Català de Paleoecologia Humana i Evolució Social (IPHES). C/Marcel.lí Domingo s/n (Edifici W3), \\ Campus Sescelades, 43007, Tarragona, Spain. \\ Àrea de Prehistoria, Universitat Rovira i Virgili (URV), Avinguda Catalunya, 35, 43002, Tarragona, Spain. \\ Email: sotoquesadamaria@gmail.com
}

\begin{abstract}
:
The Picamoixons site is a rockshelter located in the province of Tarragona (NE Iberian Peninsula). It was object of two rescue campaigns during 1988 and 1993, which led to the recovery of a complete archaeological assemblage, including stone tools as well as faunal and portable art remains that date the occupation to the $14^{\text {th }}$ to $11^{\text {th }}$ millennium BP (calibrated). This study involves a petrographic characterisation of the stone-tool assemblage in order to establish: 1) the procurement areas, 2) the raw materials management strategies and 3) the mobility radius and territorial sizes of the hunter-gatherers groups that occupied the site. The method applied comprises in a multiscale analysis that includes systematic prospection, the petrographic characterisation of geological and archaeological samples, an analysis of the chert types represented in the knapping sequence, and the definition of the mobility axes and areas frequented according to lithic procurement.

A petrographic analysis of the chert in the prospected area led to the definition of nine macroscopic varieties related to five types (Vilaplana, Morera, Maset, Vilella and Tossa cherts), related to Lower and Upper Muschelkalk (Triassic), Lutetian, Bartonian (Palaeocene) and Sannonian (Oligocene) deposits.The study of the knapping sequences indicates the main exploitation of Bartonian cherts (Tossa type), and the use of Lutetian cherts (Maset and Morera types) for configuring retouched tools. The exploitation of the remaining raw material types identified is considered sporadic and opportunistic.Defining the procurement areas enabled the mobility radius to be assessed as between 3 and $30 \mathrm{~km}$, highlighting the importance of the fluvial basins as natural movement pathways. The results indicate that the main procurement territory was $16 \mathrm{~km} 2$ in area, associable with a forager radius. The most remote procurement distances suggest a maximum exploitation area of $260 \mathrm{~km} 2$, defining an intra-regional range. This range presents parallelisms with various contemporaneous hunter-gatherers groups in Western Europe, suggesting a progressive mobility reduction dynamic during the Late Pleistocene-Initial Holocene.
\end{abstract}

Keywords: Late Pleistocene; Initial Holocene; chert; petrography; procurement; mobility

Published by the School of History, Classics and Archaeology, University of Edinburgh ISSN: 2055-0472. URL: http://journals.ed.ac.uk/lithicstudies/

This work is licensed under a Creative Commons Attribution 2.5 UK: Scotland License. 


\section{Introduction}

An absence of regional petrographic studies has made it necessary to characterise the lithic raw materials used by the Late Glacial hunter-gatherers groups around the Prades range and Camp de Tarragona region (Tarragona, NE Spain). This paper presents a systematic petrographic analysis of the lithic resources available in the contact area between the Ebro distal basin and the central sector of the Prelittoral Catalan Mountains, as well as the lithic assemblage from the Picamoixons site.

For this purpose we petrographically characterised both the geological and archaeological records to achieve our three main objectives: 1) to define the procurement areas; 2) to analyse the distribution of the different chert types in the reduction sequence; and 3 ) to delimit the mobility radius, the frequented areas and the territorial sizes of the huntergatherer groups according to the lithic procurement data.

\subsection{Picamoixons: site and stratigraphy}

The Picamoixons site is located in the left bank of the Francolí river (UTM - ETRS 89 $31 \mathrm{~N}$ 348399.2 E x; $4574166.7 \mathrm{~N}$ y) in a contact zone between the Central Catalan Depression and the Camp of Tarragona region, and close to the La Riba Strait, a connection between the Prades and the Miramar ranges (Vergés 1989).

The site was discovered in 1972 and between 1988 and 1993 it was excavated as part of a rescue program due to the deterioration of the archaeological deposits (Carbonell et al. 1989) (Figure 1).

The first intervention led to the definition of a sequence formed by two main units. The $\mathrm{CI}$, at the top, relates to the collapse of the rockshelter cornice. CII, at the base is a $2.40 \mathrm{~m}$ thick unit, formed by clays, silts, cobbles and boulders. Five different layers (CIIA to CIIE) were differentiated, three of them (A, B and D) presenting an archaeological record (Vallverdú 1994), although only the CIIA has been excavated.

A reanalysis in 2005 (Angelucci 2005) led to the partial restructuring of the stratigraphy: $\mathrm{BR}$ at the top, equivalent CI; four further units (CI1-CI4), equivalent to the CIIA-CIIC units; the TC unit, corresponding to the CIID; and finally, the Fl layer; at the base, formed by two units (Fl1 and Fl2), and relating to the fluvial deposits of the Francolí river.

The excavation was focused on the chronocultural characterization of the human occupations. The five ${ }^{14} \mathrm{C}$ results obtained date the Picamoixons sequence between $13-10 \mathrm{kyr}$ cal BP (Table 1).

Table 1. Radiocarbon dates from the Picamoixons site.

\begin{tabular}{llll}
\hline Material & Layer & Lab. ref. & Cal. BP (2s) \\
\hline Bone & Cl Base- Cll Top & AA-6010 & $10570-10170$ \\
Bone & Cl Base- CII Top & AA-6029 & $10870-10310$ \\
Bone & Cl Base- CII Top & AA-5888 & $13010-12690$ \\
Charcoal & CIIB & AA-5810 & $13150-12750$ \\
Bone & CIIA (CP) & Beta-214937 & $11140-10700$ \\
\hline
\end{tabular}

The two field seasons allowed the recovery of rich archaeological record comprising faunal, technological and artistic elements. The faunal remains are dominated by lagomorphs, Capra sp. and Bos or Bison, with Equus and Cervus also being recorded. Furthermore, three human dental pieces and a fragment of distal phalanx from at least two individuals were also recovered. 

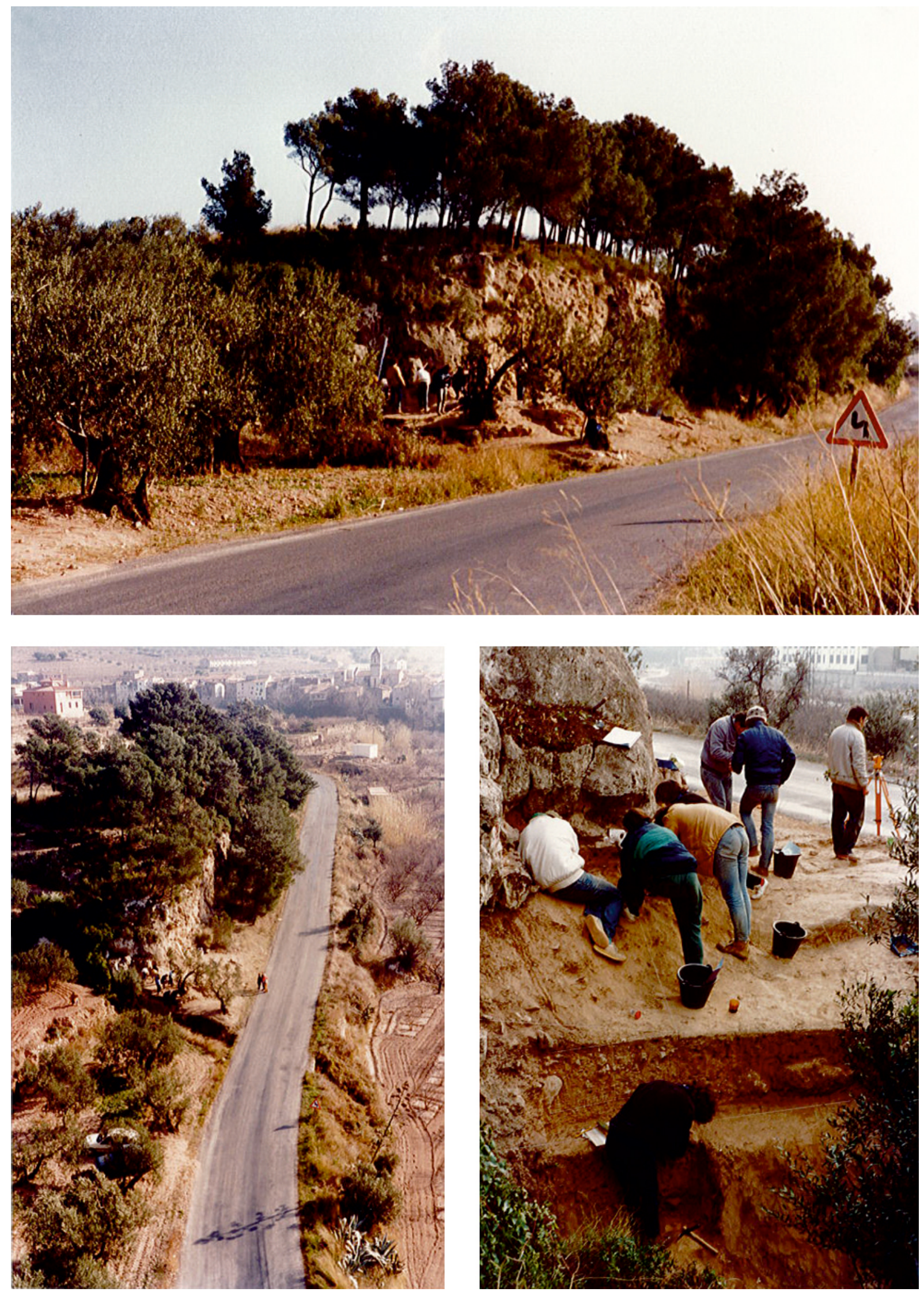

Figure 1.General location of the Picamoixons site (Picamoixons) (left). General image (centre) and detail of the fieldwork (right) carried out in 1988 (J.M. Gabarró). 
The lithic assemblage is composed of ca. 900 remains, and displays the classical dominance of endscrapers and backed blades that regionally define the Late Glacial and Early Holocene periods (Morales 2012). Recently, the lithic assemblage from the CIIA layer has beem subdivided into two separate assemblages according to spatial distribution and the degree of patination (García Catalán et al. 2009).

Additionally, two fragments of portable art, a limestone slab with pigment strokes forming seven a crayon-lines were also documented (García Díez et al. 1997).

\section{Materials}

A regional lithoteca comprising more than 100 hand samples has been created as a reference collection. From these hand samples a total of 60 uncovered thin-sections have been prepared (Figure 2). This collection was used for comparative purposes during the analysis of the archaeological assemblage.
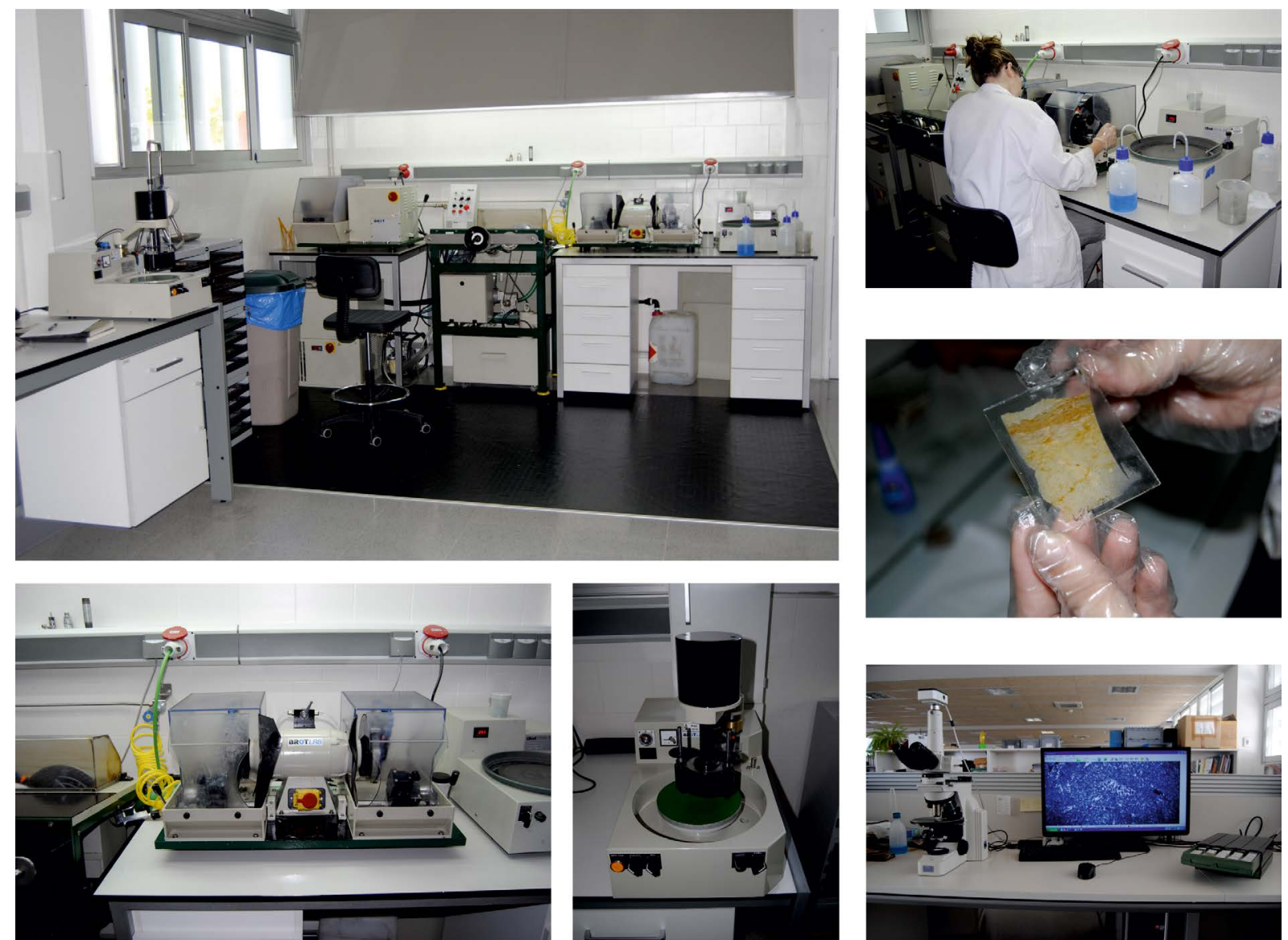

Figure 2. Thin-section and analysis equipment at the Geoarchaeology facilities at IPHES.

The assemblage recovered during the 1993 field-season was selected for this study. These samples are characterised by the dominance of knapping products (67\%) retouched elements (10\%), cores (4\%), fragments (13\%) and natural bases (6\%) (Figure 3). The relative variability of raw materials including limestone, schist, slate, quartz, sandstone and porphyr has been also documented.

In this work we only present the results of the chert analysis, not including the nonsiliceous rocks. During the work, the $16 \%$ of the sample was also excluded from the analysis due to the presence of heavy fire damage and several alterations. 

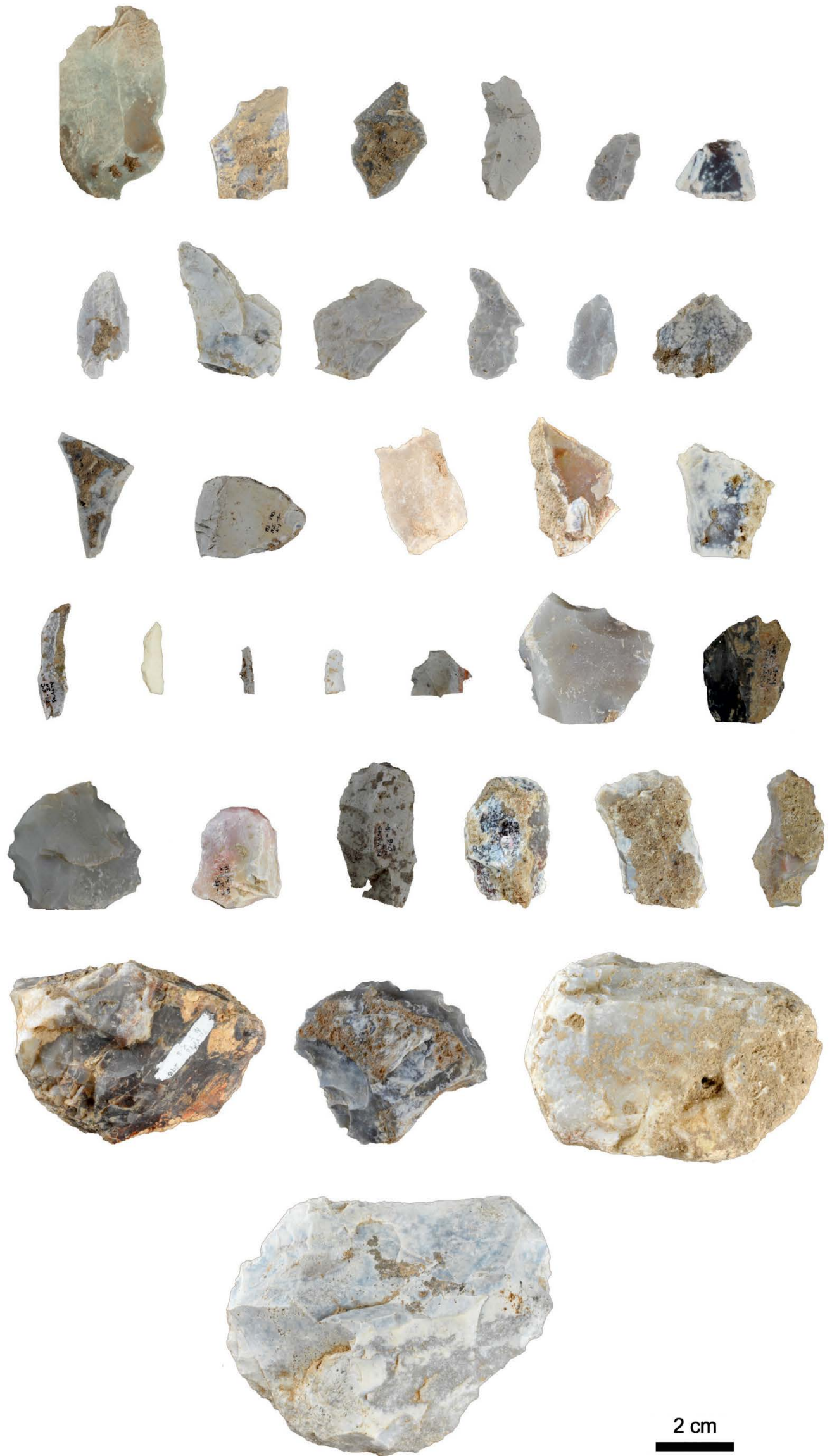

$2 \mathrm{~cm}$

Figure 3. Sample of the lithic assemblage of the CIIA level at Picamoixons site. Flakes, blades, backed bladelets, denticulates, endscrapers and cores. 


\section{Methods}

The methods applied in this study consisted of a multiscale analysis, with the purpose of creating a catalogue of empirical descriptions for interpreting lithic procurement strategies and territorial management.

These analyses are grouped into four research aspects: the prospection, a petrographic characterization of the geological and archaeological record, statistical analysis to the employed raw materials, and the definition of the exploited areas and mobility routes.

\subsection{Prospection}

Cartographic and bibliographical research was used to delimit the geological chertbearing units, in order to establish the baseline information for the fieldwork. The field surveys allowed the outcrops to be located and catalogued, and both the siliceous nodules and their enclosing rocks were systematically sampled to reflect the variability and availability of raw materials in the landscape.

\subsection{Petrographic characterisation}

The macroscopic and microscopic characteristics of the reference collection and the archaeological assemblage were petrographycally analysed.

The morphoscopic characters observed $a$ visu and as well as with a binocular microscope (at x32/40 magnification) to classify both the external traits and the internal features of the rocks (e.g., colour, transparency, texture, sedimentary structures, fissures, and inclusions...).

The thin-sections were analysed using a polarising light microscope (at x20/200 magnification) to define the texture and mineralogy of the siliceous and non-siliceous components.

The siliceous components observed include crystalline silica as well as granular quartz (mega-, micro- and cryptoquartz), fibrous textures (chalcedony, quartzine, lutecite and mixed forms) (Arbey 1980).

The analysis of non-siliceous components focused on the identification and mineralogical definition of: a) carbonates: differentiating between allochemical and orthochemical elements (Bathrust 1975; Boggs 2009; Folk 1959; Humbert 1976; Tucker \& Wright 1990); b) evaporites: distinguishing between primary or secondary gypsum and anhydrite (Kendall 1979; Sonnefeld 1979; Warren 2010); c) iron oxides; and d) terrigenous or detrital elements.

\subsection{Raw materials in the archaeological record}

The petrographic analysis of the reference collection enabled a classification of the raw materials recovered at the Picamoixons site as well a statistical analysis of the distribution percentages in the structural categories of the knapping sequence.

The Chi-square distribution test was also applied in order to define the raw materials management dynamics at an intra-site scale.

This test $\left(\mathrm{X}^{2}=\Sigma(\mathrm{O}-\mathrm{T})^{2} / \mathrm{T}\right)$ is based on comparing the data observed in the archaeological assemblage $(\mathrm{O})$ with respect to the theoretical values $(T=$ (n remains associated to $X$ structural category * no. remains of $\mathrm{X}$ raw material) / Total archaeological remains) that the CIIA level must present in order to consider its distribution random $\left(\mathrm{X}^{2}<3.84\right)$. For this reason, values above 3.84 inferred to represent differential management patterns in the exploitation of raw materials (Tarriño 2006). 


\subsection{Lithic procurement: mobility, frequented areas and territorial sizes}

Combining the previous results allows a definition of the procurement dynamics and exploited territories, delimiting the principal areas frequented by the groups that occupied the Picamoixons site.

These most-frequented areas point to mobility routes, which we have mapped using a GIS procedure that defines the territories with least displacement cost according to the slope gradients (Binford 1983; Brannan 1992; Elston 1992; Hodder \& Orton 1976). All these results allowed us to establish the mobility type and dimensions of the procurement territories (Dyson-Hudson 1978; Féblot-Augustins 2009; Grove 2009; 2010; Wobst 1974).

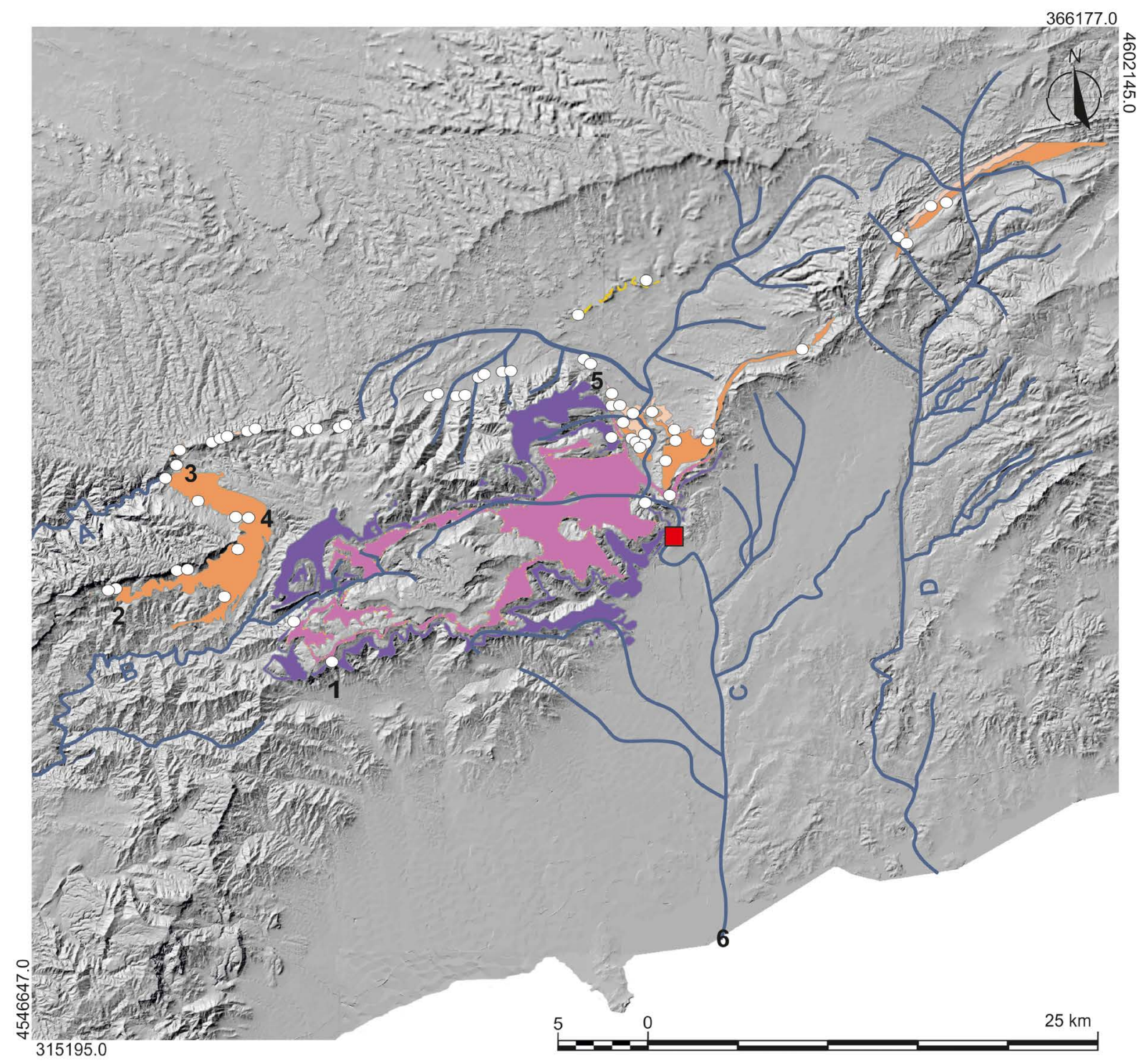

LEGEND: $\square$ Picamoixons site. - Watercourses: A. Montsant river; B. Siurana river; C. Francolí river D. Gaià river. Geochronological units with silicifications: $\square$ Lower Muschelkalk; $\square$ Upper Muschelkalk; $\square$ Lutetian; $\square$ Bartonian; $\square$ Sannonian. $\bigcirc$ Chert outcrops .Locality type: 1. Vilaplana; 2. Morera del Montsant; 3. Ulldemolins; 4. Albarca; 5. Montblanc; 6. Tarragona.

Figure 4. General map of the prospected area (ETRS89). 


\section{Results}

\subsection{Prospection and available chert resources}

A total of 56 different primary chert outcrops were defined after the prospecting campaigns around the Montsant, Prades and Miramar ranges. These outcrops are related to four geochronological units: the Lower and Upper Muschelkalk (Triassic), Lutetian (Paleocene) and Sannonian (Oligocene) (Soto 2015) (Figure 4).

Five siliceous types were identified according to their petrographic characteristics and these were named according to the place name of the model outcrop, defined by the highest chert abundance ratios. These are Vilaplana chert (Vilaplana), Morera chert (Morera del Montsant), Maset chert (Ulldemolins), Vilella chert (Albarca) and Tossa chert (Montblanc).

These chert types presented several morphoscopic varieties that forced us to establish a catalogue containing the various recognizable macroscopic features. In the end, the reference collection comprises a total of 17 chert subtypes that can be compared to the archaeological assemblage from the CIIA layer.

\subsection{Petrographic characterisation}

The comparison between the lithoteca and the archaeological material from the archaeological CIIA layer of Picamoixons confirmed the presence of nine (Figure 5) of the chert sub-varieties described (Table 2).

a)

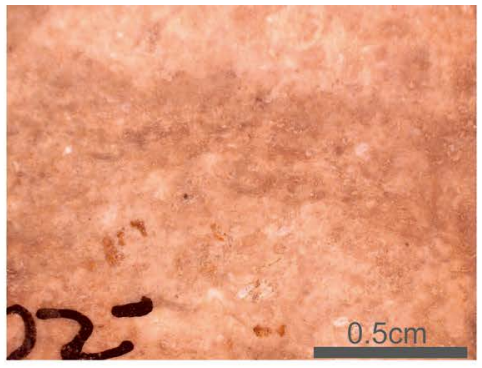

d)

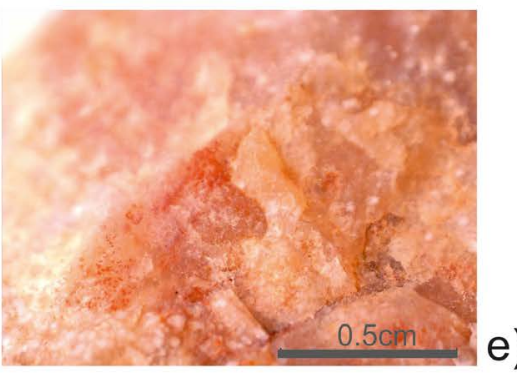

b)

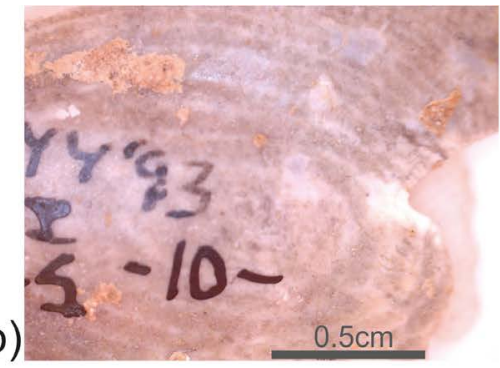

e)

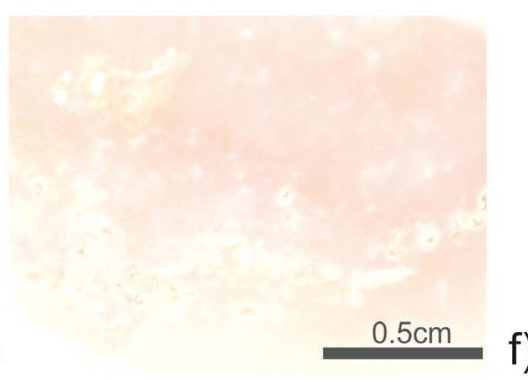

c)
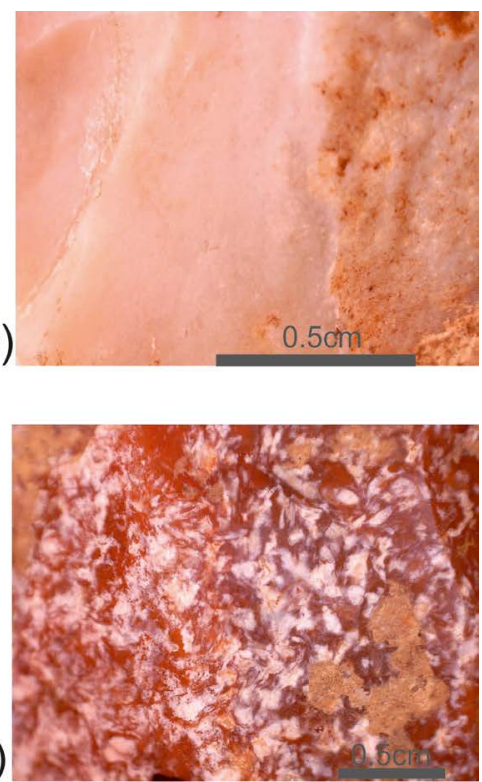
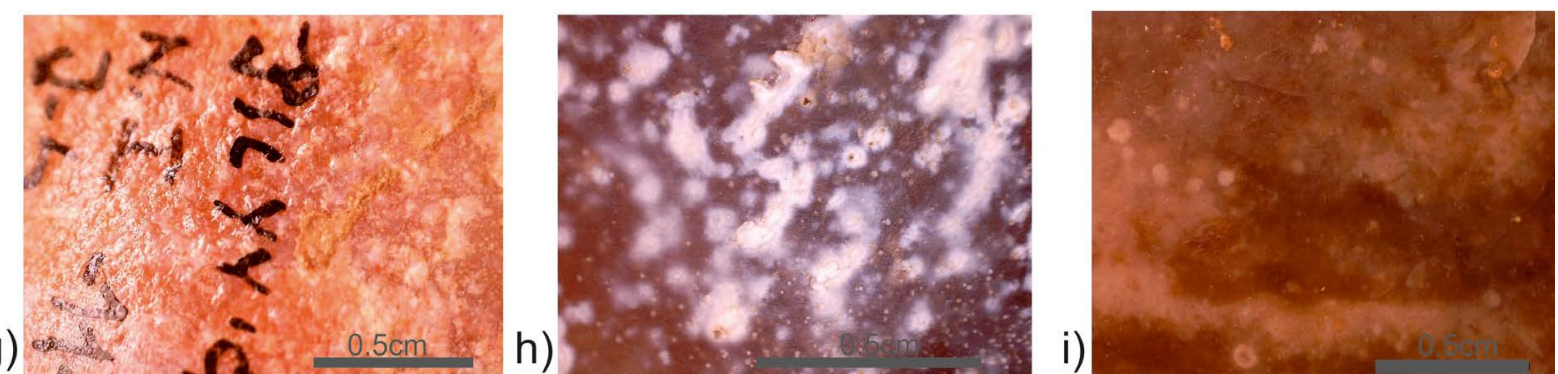

Figure 5. Macroscopic aspect of the chert varieties identified in the CIIA layer from the Picamoixons site: a) Vilaplana 1; b) Vilaplana 2; c) Morera 1; d) Morera 2; e) Maset 2; f) Maset 3; g) Vilella 1; h) Tossa 1; i) Tossa 2. 
Table 2. Main characteristics of the chert varieties identified. Abbreviations: Col. - colour ; LG - light grey; G - grey; WG - white-grey; GB - grey-blue; W - white; R - red; Bk - black; F - fine; VF - very fine; C - coarse; Transp. - transparency; O - opaque; T - translucent; Allochem. elem. - allochemical elements; Sedim. struct. - sedimentary structure; MS - mudstone; WS - wackestone; CC - crystalline carbonates; NR - non-recognisable;

\begin{tabular}{|c|c|c|c|c|c|c|c|c|c|c|}
\hline & & \multicolumn{7}{|c|}{ Macroscopic Features } & \multicolumn{2}{|c|}{ Microscopic Features } \\
\hline & & & Grain & & & Allochem. & & & & \\
\hline & & Col. & -size & Transp. & Inclusions & elem. & Sedim. struct. & Texture & Pp Light & Xp Light \\
\hline \multirow[t]{2}{*}{$\begin{array}{l}\text { Vilaplana Chert - } \\
\text { Silicified marine } \\
\text { limestones }\end{array}$} & Vilaplana 1 & LG & $\mathrm{F}$ & 0 & $\begin{array}{l}\text { Organic materials, } \\
\text { gypsum } \\
\text { pseudomorphs, } \\
\text { iron oxides }\end{array}$ & $\begin{array}{l}\text { Carbonate } \\
\text { relicts, } \\
\text { bioclasts }\end{array}$ & - & $\begin{array}{l}\text { MS or } \\
\text { WS }\end{array}$ & \multirow{2}{*}{$\begin{array}{c}\text { Calcispheres, } \\
\text { spicules, ostracodes. } \\
\text { Micritic matrix, clay } \\
\text { minerals, haematite, } \\
\text { gypsifeorus relicts }\end{array}$} & \multirow{2}{*}{$\begin{array}{l}\text { Microcrystalline } \\
\text { quartz, } \\
\text { chalcedonite, } \\
\text { quartzine and } \\
\text { lutecite }\end{array}$} \\
\hline & Vilaplana 2 & G & $\begin{array}{l}\text { F or } \\
V F\end{array}$ & 0 & Iron oxides & $\begin{array}{c}\text { Intraclasts, } \\
\text { bioclasts }\end{array}$ & $\begin{array}{l}\text { Liesengang } \\
\text { rings }\end{array}$ & WS & & \\
\hline \multirow{2}{*}{$\begin{array}{l}\text { Morera Chert - } \\
\text { Diagenetic } \\
\text { replacement } \\
\text { from secondary } \\
\text { gypsums and } \\
\text { gypsiferous marls }\end{array}$} & Morera 1 & WG & $\begin{array}{l}\text { F or } \\
\text { VF }\end{array}$ & 0 & $\begin{array}{l}\text { Lenticular-tabular } \\
\text { gypsum, iron } \\
\text { oxides, anhydrite }\end{array}$ & - & $\begin{array}{c}\text { Contorted } \\
\text { paterns } \\
\text { (Chicken-wire) }\end{array}$ & $\mathrm{NR}$ & \multirow{2}{*}{$\begin{array}{l}\text { Microsparitic calcite, } \\
\text { micrític mud, ooids, } \\
\text { lenticular gypsum, } \\
\text { clay minerals, } \\
\text { haematite }\end{array}$} & \multirow[t]{2}{*}{$\begin{array}{l}\text { Microcrystalline and } \\
\text { length-slow quartz }\end{array}$} \\
\hline & Morera 2 & GB & $\mathrm{C}$ & O & $\begin{array}{l}\text { Lenticular gypsum, } \\
\text { anhydrite, iron } \\
\text { oxides }\end{array}$ & - & Stylolites & NR & & \\
\hline \multirow{2}{*}{$\begin{array}{l}\text { Maset Chert - } \\
\text { Diagenetic } \\
\text { replacement } \\
\text { from nodular } \\
\text { primary gypsums }\end{array}$} & Maset 2 & W & $\begin{array}{l}\text { F or } \\
\text { VF }\end{array}$ & $\mathrm{T}$ & Evaporitic relicts & - & $\begin{array}{l}\text { Endocortical } \\
\text { laminations }\end{array}$ & NR & \multirow{2}{*}{$\begin{array}{l}\text { Lenticular gypsum, } \\
\text { calcite, haematite, } \\
\text { ocasional carbonate } \\
\text { intraclasts }\end{array}$} & \multirow{2}{*}{$\begin{array}{c}\text { Micro- and } \\
\text { macrocrystalline } \\
\text { quartz, lutecite and } \\
\text { quartzine }\end{array}$} \\
\hline & Maset 3 & $\mathrm{R}$ & $\begin{array}{l}\text { F or } \\
\text { VF }\end{array}$ & $\mathrm{T}$ & $\begin{array}{l}\text { Lenticular gypsum, } \\
\text { anhydrite, iron } \\
\text { oxids }\end{array}$ & - & $\begin{array}{c}\text { Contorted } \\
\text { patterns, } \\
\text { laminations, } \\
\text { biogenic scape } \\
\text { figures }\end{array}$ & NR & & \\
\hline $\begin{array}{l}\text { Vilella Chert - } \\
\text { Diagenetic } \\
\text { replacement } \\
\text { from gypsilutitic- } \\
\text { oxide-rich facies }\end{array}$ & Vilella 1 & $\mathrm{R}$ & $\begin{array}{l}\text { F or } \\
\text { VF }\end{array}$ & O & $\begin{array}{l}\text { Lenticular gypsum, } \\
\text { anhydrite, iron } \\
\text { oxides }\end{array}$ & - & $\begin{array}{l}\text { Enterolithic } \\
\text { patterns, } \\
\text { laminations } \\
\text { and stylolites }\end{array}$ & NR & $\begin{array}{l}\text { Lenticular gypsum, } \\
\text { calcite intraclasts, } \\
\text { ooids, fibrous } \\
\text { hematite }\end{array}$ & $\begin{array}{l}\text { Micro- and } \\
\text { cryptocrystalline } \\
\text { quartz , quartzine, } \\
\text { lutecite and } \\
\text { chalcedonite }\end{array}$ \\
\hline \multirow{2}{*}{$\begin{array}{l}\text { Tossa Chert - } \\
\text { Diagenetic } \\
\text { replacement } \\
\text { from marly } \\
\text { limestones }\end{array}$} & Tossa 1 & G & $\begin{array}{l}\text { F or } \\
\text { VF }\end{array}$ & $\mathrm{T}$ & $\begin{array}{c}\text { Carbonates, iron } \\
\text { oxides, lenticular } \\
\text { gypsum }\end{array}$ & - & - & $\mathrm{CC}$ & \multirow{2}{*}{$\begin{array}{c}\text { Lenticular gypsum, } \\
\text { prismatic anhydrite, } \\
\text { clay minerals, ooids, } \\
\text { haematite, pyrite, } \\
\text { fluorite }\end{array}$} & \multirow{2}{*}{$\begin{array}{c}\text { Micro- and } \\
\text { macrocrystalline } \\
\text { quartz, length- slow } \\
\text { and lenght-fast } \\
\text { fiborus quartz, } \\
\text { sparitic carbonates }\end{array}$} \\
\hline & Tossa 2 & $\mathrm{Bk}$ & $\begin{array}{l}\text { F or } \\
\text { VF }\end{array}$ & O & $\begin{array}{l}\text { Iron oxides, } \\
\text { evaporite relicts }\end{array}$ & Intraclasts & - & $\mathrm{CC}$ & & \\
\hline
\end{tabular}




\subsubsection{Vilaplana chert (Vilaplana)}

Two macroscopic varieties (Vilaplana 1 and Vilaplana 2), were identified in 12 remains from the assemblage (Figure $5 \mathrm{a}$ and $\mathrm{b}$ ).

Vilaplana1 is a fine grained opaque chert, with light greyish tones (Very Light Grey N8, Light Brown 5YR 6/4, Pale Brown 5YR 5/2). Organic materials, gypsum pseudomorphs, iron oxides inclusions, carbonate relicts and bioclasts are also present, defining Vilaplana1 as mudstone or wackestone chert (Dunham 1962).

The second Vilaplana variety is a xyloidal chert, with opaque surfaces, fine or very fine textures and greyish colours (10 YR 8/6 Pale Yellowish Orange, 10 YR 6/2 Pale Yellowish Brown) presenting carbonate inclusions, iron oxides and Liesegang rings as sedimentary structures (Mangado 2004; Vera \& Molina 2001).

The petrographic analysis indicates the presence of skeletal carbonates clasts (spicules, ostracodes, gasteropods) and not (intraclasts and calcispheres), as components prior to silicification. Cryptocrystalline clay mineral, massive haematite, and isolated gypsiferous lenticular pseudomorphs $(80-120 \mu \mathrm{m})$ have been also observed in a micritic matrix (Figure 6), generating mudstones or packstones textures.

The crossed-polar analysis shows that the dominant texture is microcrystalline quartz, as diagenetically replacing the carbonated matrix (Figure 7). Spherulithic chalcedonite and quartzine and lutecite complete the spectrum of siliceous components forming in the intraparticular pores and cementing together the allochemical elements.
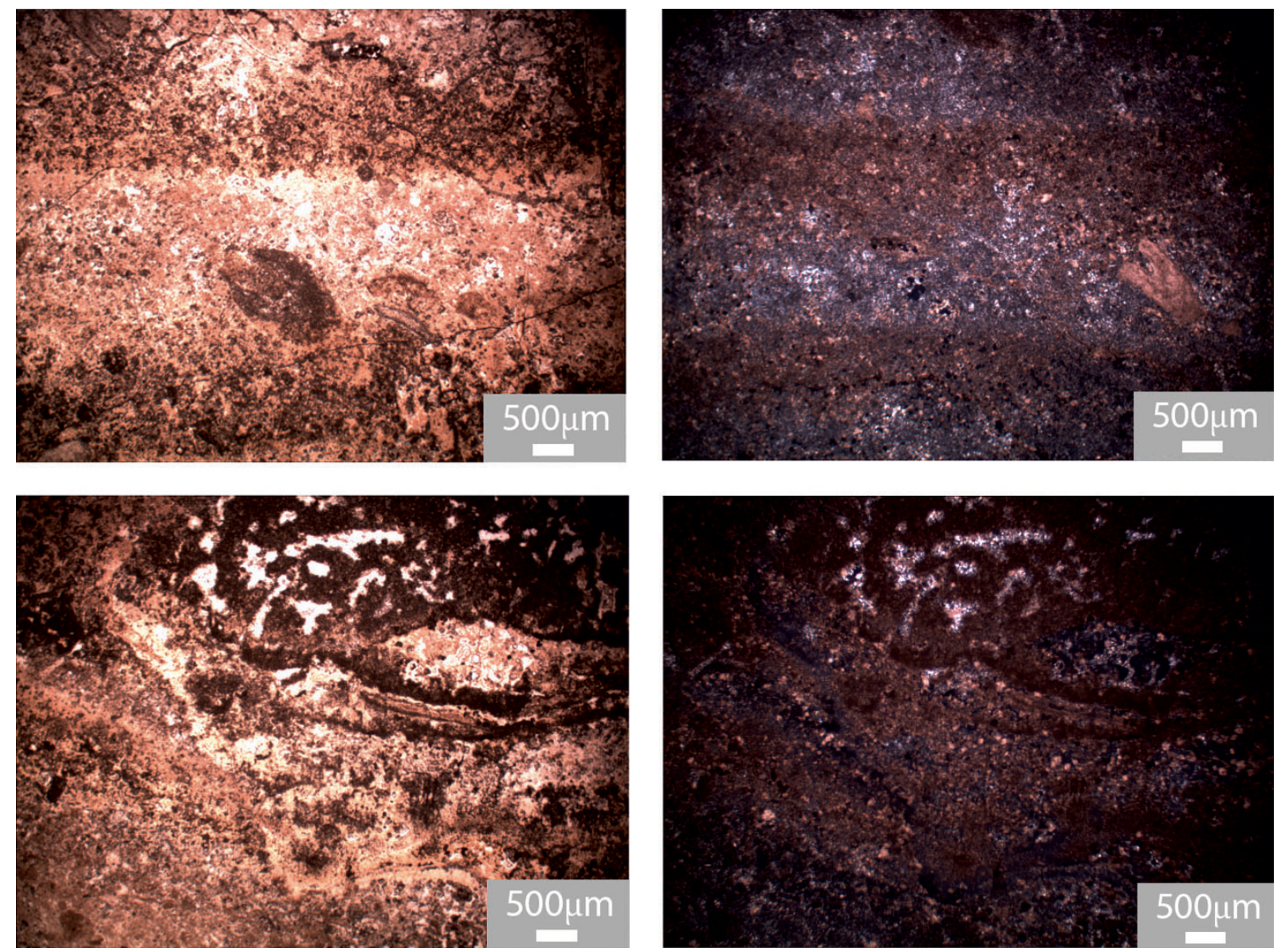

Figure 6. Thin section images of Vilaplana chert. Left: The laminated carbonate elements (Liesegang rings) create a packstone texture. Right: The samples in crossed polarised light reveal a differential siliceous content configuring the xyloidal aspect. 

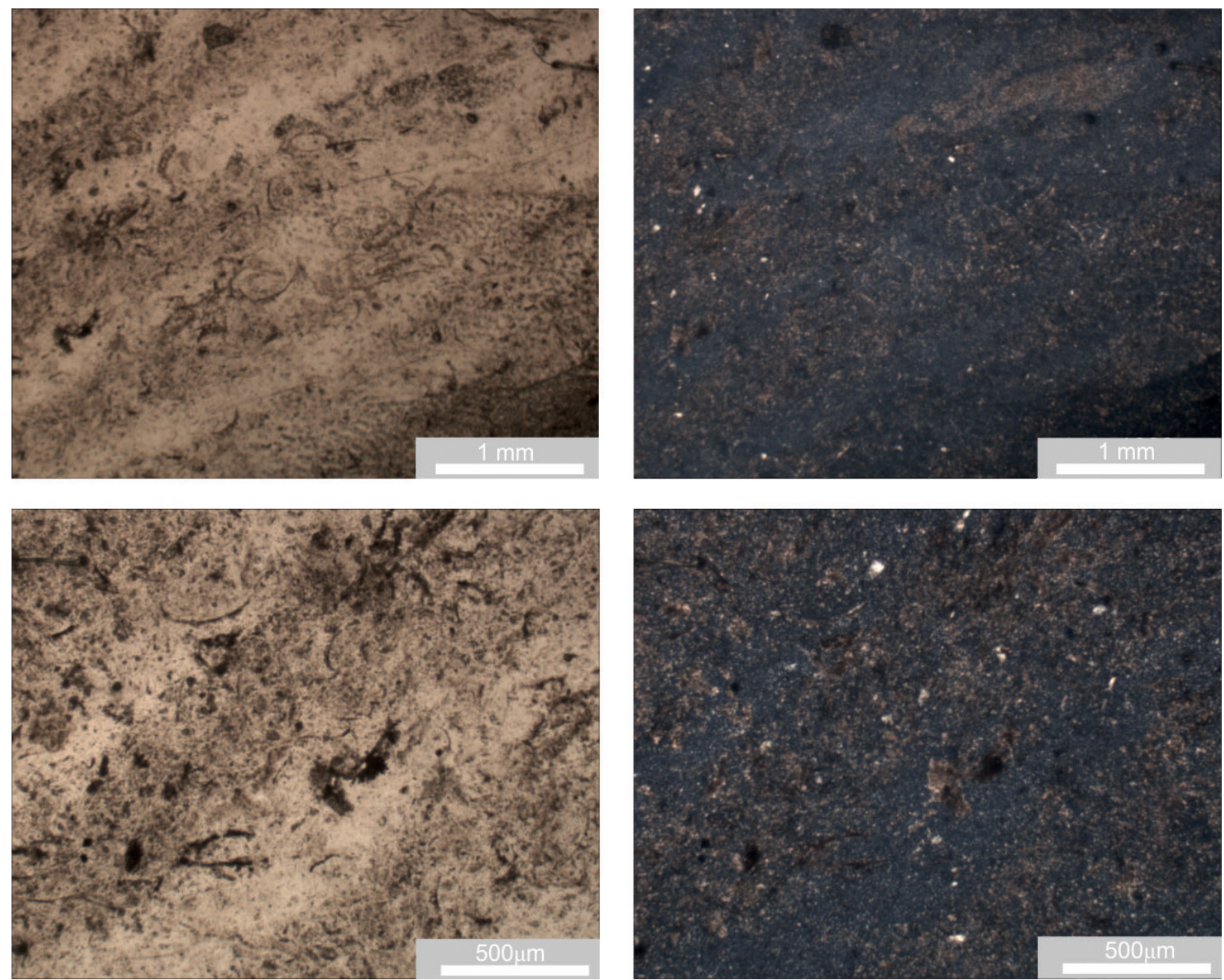

Figure 7. Xyloidal chert from the Picamoixons assemblage. Left: Images with plane polarizer where the primary depositional texture and Liesegang rings can be seen. Right: Crossed polarised light reveals the presence of micro- and cryptoquartz as well as detrital quartz.

\subsubsection{Morera chert (Morera del Montsant)}

Two macroscopic varieties of this Lutetatian chert (Morera 1 and 2) have been described in 32 remains from the CIIA assemblage (Figure $5 \mathrm{c}$ and d)

Morera1 is characterised by a whitish and greyish colours (Very Light Grey N8, Yellowish Grey 5Y 8/1, Greyish pink 5R 8/2) and opaque and matt surfaces, with fine or very fine textures and frequent fissures. There are occasional lenticular and tabular gypsum crystals, iron oxides and contorted dark patterns, related to the presence of chicken-wire anhydrite (Ortí 2012).

Morera 2 is light greyish-bluish in colours (Very Light Grey N7, Medium Grey N5, Light Bluish Grey 5B 7/1, Pale Blue 5PB 7/2, Greyish Blue 5PB 5/2) and matt aspect. Macroscopically the texture is coarse and heterogeneous, and there are lenticular crystals, gypsum pseudomorphs, anhydrite relicts, secondary gypsum and iron oxides present. The sedimentary structures include pressure figures or stylolites (Collinson et al. 2006).

The microscopic analysis reveals a siliceous body mainly microcrystalline in texture with spherulitic length-slow fibrous quartz (40-50\%) (Figure 8). Microsparitic calcite (20-100 $\mu \mathrm{m})$, micritic mud (10-20\%) and ooids with microcrystalline cement have been also described and are related to the primary depositional texture. Furthermore, isolated lenticular gypsum crystals (300-500 $\mu \mathrm{m})$, clay minerals and globular aggregates and fine-grained haematite have been described in vugs and fissures. 

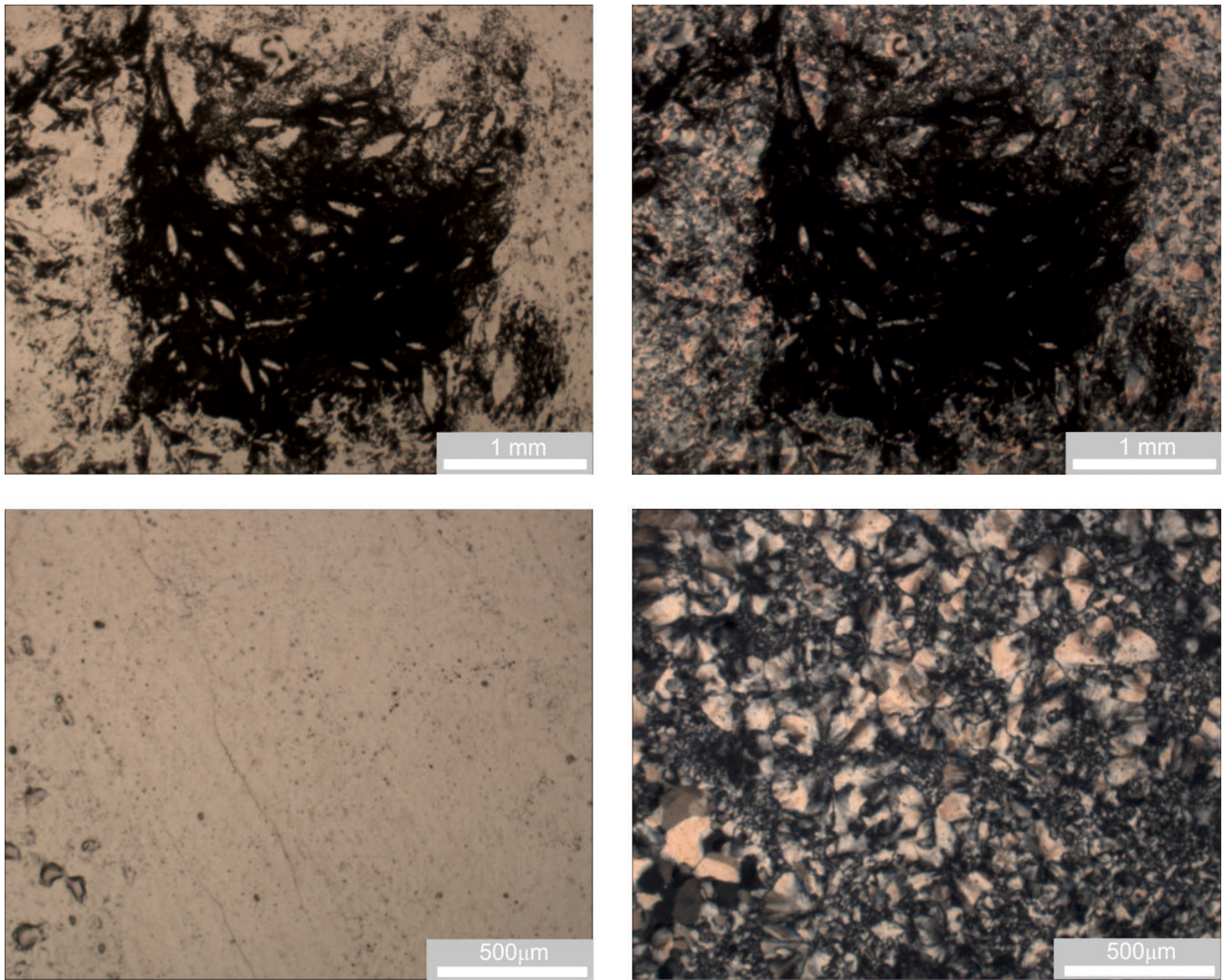

Figure 8. Thin section of Morera1 chert. Images with normal polariser (left) and crossed polariser (right). Detail of a dissolution cavity filled with clay minerals, gypsiferous pseudomorphs, and fibrous and microcrystalline quartz.

The features related to the primary depositional textures suggest a siliceous replacement process where the microcrystalline quartz substituted the matrix and the fibrous quartz cemented the dissolution hollows forms obliterated.

\subsubsection{Maset chert (Ulldemolins)}

Two macroscopic varieties (Maset 2 and 3) (Figure 5 e and f) have been identified in 75 remains form the archaeological assemblage.

Maset 2 is a white-coloured chert (Very Light Grey N8, White N9), with translucent surfaces and a fine or very fine texture. There are occasional carbonate inclusions, iron oxides and evaporitic relicts (gypsum pseudomorphs and lenticular crystals or chicken-wire anhydrite patterns). This variety presents endocortical laminations as sedimentary structures, but there are also post-diagenetic fissures present.

Maset 3 is a reddish-coloured chert (Pale Reddish Brown 10R5/4, Moderate Red 5R 5/4), with translucent and matt surfaces as well as a fine or very fine texture. Iron oxides and evaporitic relicts, gypsum pseudomorphs, lenticular crystals, and anhydrite structures have been also observed. They present occasional laminations and probably biogenic escape figures, related to subaerial exposure and karstification processes. There are also isolated cavities, less than $1 \mathrm{~cm}$, with gypsum and halyte crystals-covered walls. Some remains 
associated with this raw material have a high degree of white patina due to superficial silica remobilisation (Fernandes 2012; Schmalz 1960) causing a banded aspect in the colour distribution.

The petrological analysis reveals a surface comprising lenticular and nodular gypsum crystals $(100-300 \mu \mathrm{m})$ with equant microcrystalline calcite cement, cryptocrystalline haematite (1-2\%) and occasional carbonate intraclasts $(10-15 \mu \mathrm{m})$ (Tucker \& Wright 1990). Some samples present microsparitic calcite crystals and massive haematite, confirming a carbonate replacement process and an iron-oxides removal-concentration in the inner part and along the contours of the gypsiferous pseudomorphs.

The isometric microcrystalline quartz, caused by cement replacement, is the main siliceous component, accounting for $50-60 \%$ of the samples. Macrocrystalline isometric quartz associations $(100-120 \mu \mathrm{m})$ are occasionally described filling the cavities left by the chemical dissolution of gypsum.

Elongated fibrous quartz $(250 \mu \mathrm{m})$ defined as lutecite and quartzine cement the intercrystalline pores of the gypsum pseudomorphs, lenticular crystals and iron oxides (110\%) (Figure 9).

The petrographic analysis defines these materials as being a product of the diagenetic replacement of nodular primary gypsum.

\subsubsection{Vilella chert (Albarca)}

Only one variety of Vilella chert, the Vilella 1 subtype, (Figure 5g) has been defined in the archaeological assemblage.

It is characterized by reddish mottling (Pale reddish brown 10R 5/4, Moderate Red 5R 4/6, Dusky Red 5R 3/4), with matt and opaque surfaces and fine or very fine textures. Evaporitic crystals and relicts, forming enterolithic patterns, and iron oxides inclusions, have been observed. There are laminations and pressure figures, or stylolites, related to biogenic processes and phases prior to silicification.

Observation in plane polarised light reveals the presence of fibrous haematite (30-40\%), clay minerals (10-20\%) and calcite intraclasts and ooids (1\%) as a matrix for lenticular gypsum crystals $(200 \mu \mathrm{m}-1 \mathrm{~mm})$.

Microcrystalline isometric and cryptocrystalline quartz (50-60\%) are the main components seen under crossed polarized light. These represent the siliceous cement of a primary lutitic matrix. Fibrous quartz of both elongations is also present: quartzine and lutecite have replaced the gypsiferous pseudomorphs and chalcedonite cemented the occasional carbonate components prior to the silicification (Figure 10).

This chert type presents frequent primary microstructures, tunnels or shafts, related to desiccation cracks or moderate biological activity, and is cemented by crypto- and microcrystalline quartz.

Secondary porosity or vugs, the product of chemical dissolution, and fractures, filled by secondary alabastrine gypsum, anhydrite and evaporitic breccias are also described.

This chert originated from the diagenetic replacement processes from gypsilutitic-oxiderich facies, with chemical dissolution, subaerial exposure and bioturbations.

\subsubsection{Tossa chert (Montblanc)}

Two varieties, Tossa 1 and 2, have been observed in 141 lithic remains (Figure $5 \mathrm{~h}$ and i).

Tossa 1 presents grey colours (Light Grey N6, Medium Grey N4), matt and translucent surfaces and fine or very fine textures. Carbonate inclusions, iron oxides and lenticular gypsum can also be identified. Allochemical elements are poorly represented, suggesting silicification from mudstones or crystalline carbonates. 
Tossa 2 is characterised by blackish colours (Medium Dark Grey N4, Greyish Black N2), opaque surfaces and fine or very fine textures, as well as the presence of iron oxides, evaporite relicts, allochemical elements and a mudstone or crystalline carbonate chert texture.
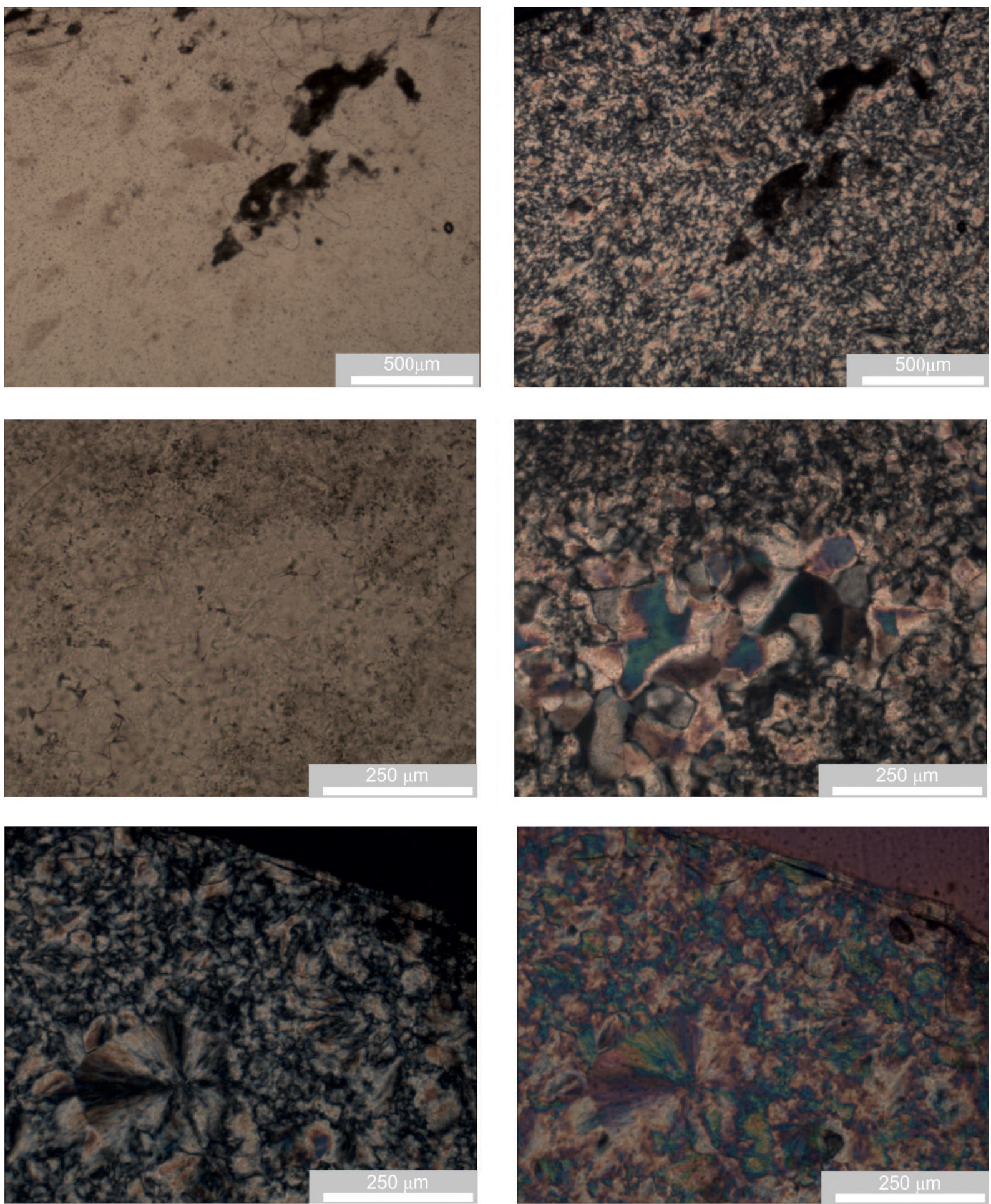

Figure 9. Thin section images of Maset 2 chert. Gypsum pseudomorphs with haematite concentrations (Above); chemical dissolution cavities cemented by macrocrystaline quartz in mosaic (centre); replacement of the primary depositional texture by microcrystalline quartz and length-positive fibrous quartz (down). 

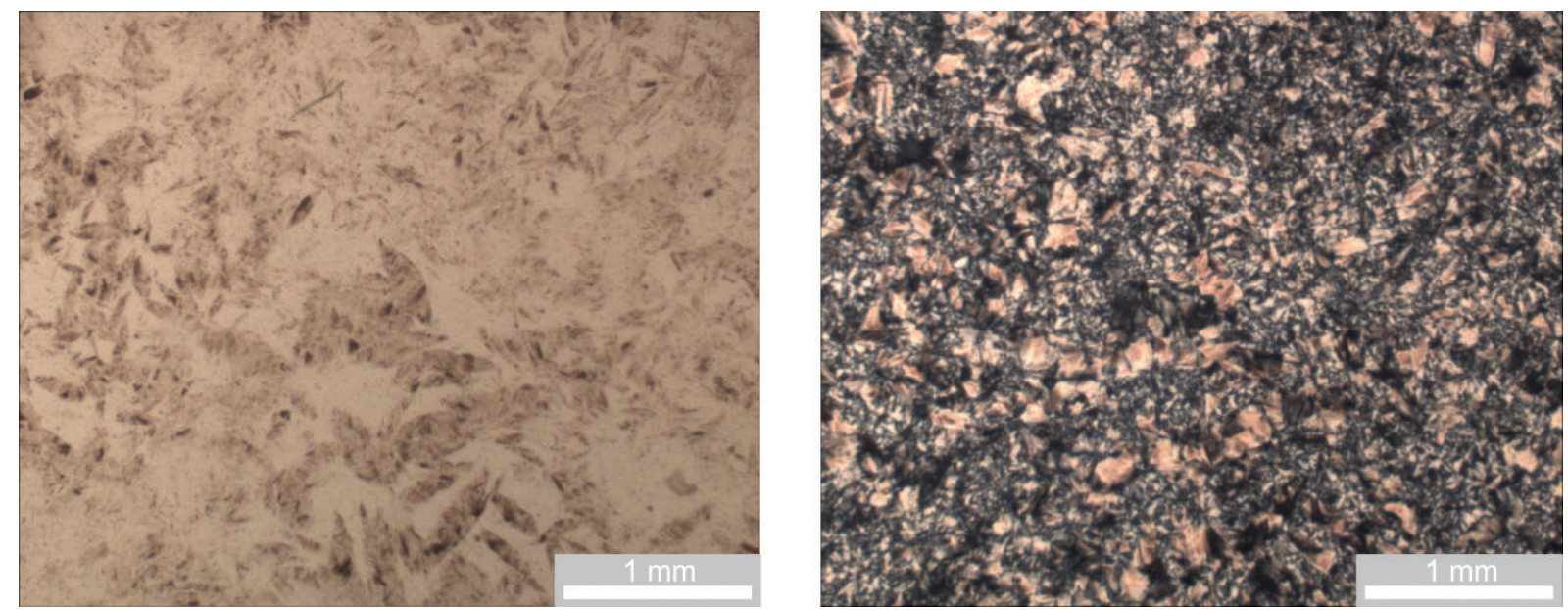

Figure 10. Archaeological sample of Vilella 1 chert. Left: Lenticular gypsum with haematite and dissolution structures. Right: microcrystaline and fibrous quartz can be seen in crossed polarised light.

The siliceous body is composed of isometric microcrystalline quartz, lenticular gypsum pseudomorphs, prismatic microgranular anhydrite, ocassional ferruginous ooids, massive haematite, pyrite and fluorite.

The micro- and cryptocrystalline quartz cement the micritic matrix that is partially preserved in the samples. This matrix supports sparitic calcite, gypsiferous pseudomorphs and anhydrite microcrystals with fine haematite inclusions (Figure 11).

The moldic porosity of the gypsiferous relicts is cemented by quartzine and lutecite, while the carbonates are occasionally replaced by botroydal and spherulitic length-fast chalcedony.
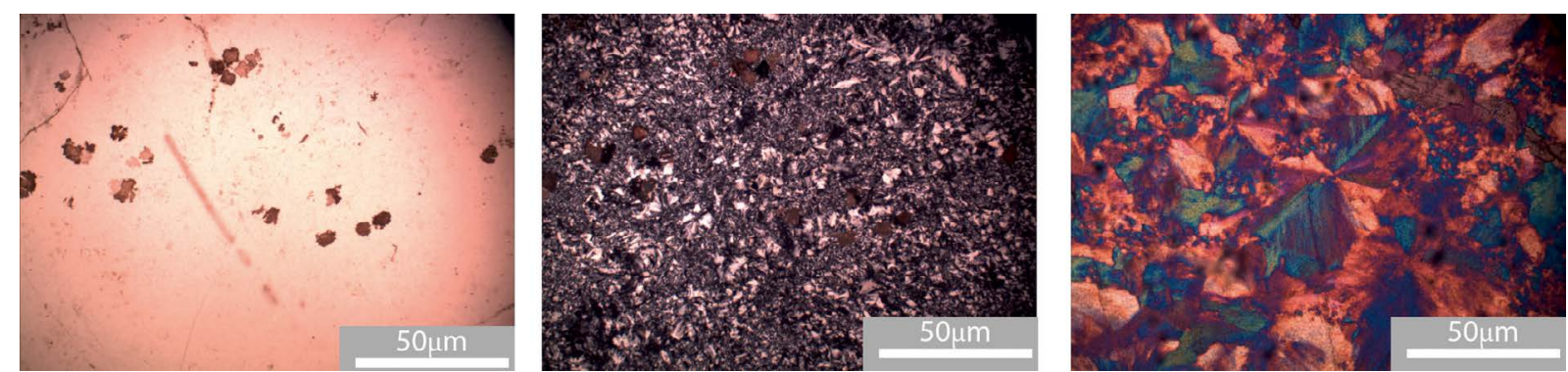

Figure 11. Thin sections of Tossa chert type. Left: Calcite intraclasts. Centre: Isometric microquartz. Right: Detail of lutecite replacing a gypsiferous pseudomorph.

Thin-sections show frequent dissolution microstructures, defined as vugs. Clay minerals, brecciated gypsum crystals, partially cemented by tiled and puzzle macrocrystalline quartz (up to $300 \mu \mathrm{m}$ ), and equigranular sparitic carbonates related to microcodia (Figure 12) originated from the calcification of vegetal matter (Stoops 2003) are observed inside these vugs.

Planes and fractures are filled by alabastrine gypsum or by blocky-type calcite, with palisadic macrocrystalline quartz along their boundaries.

The petrographic analysis indicates that Tossa chert is product of early diagenesis from marly limestone in a phreatic or buried environment according to the cortical areas analysed and the similarities established with the enclosing rocks. 

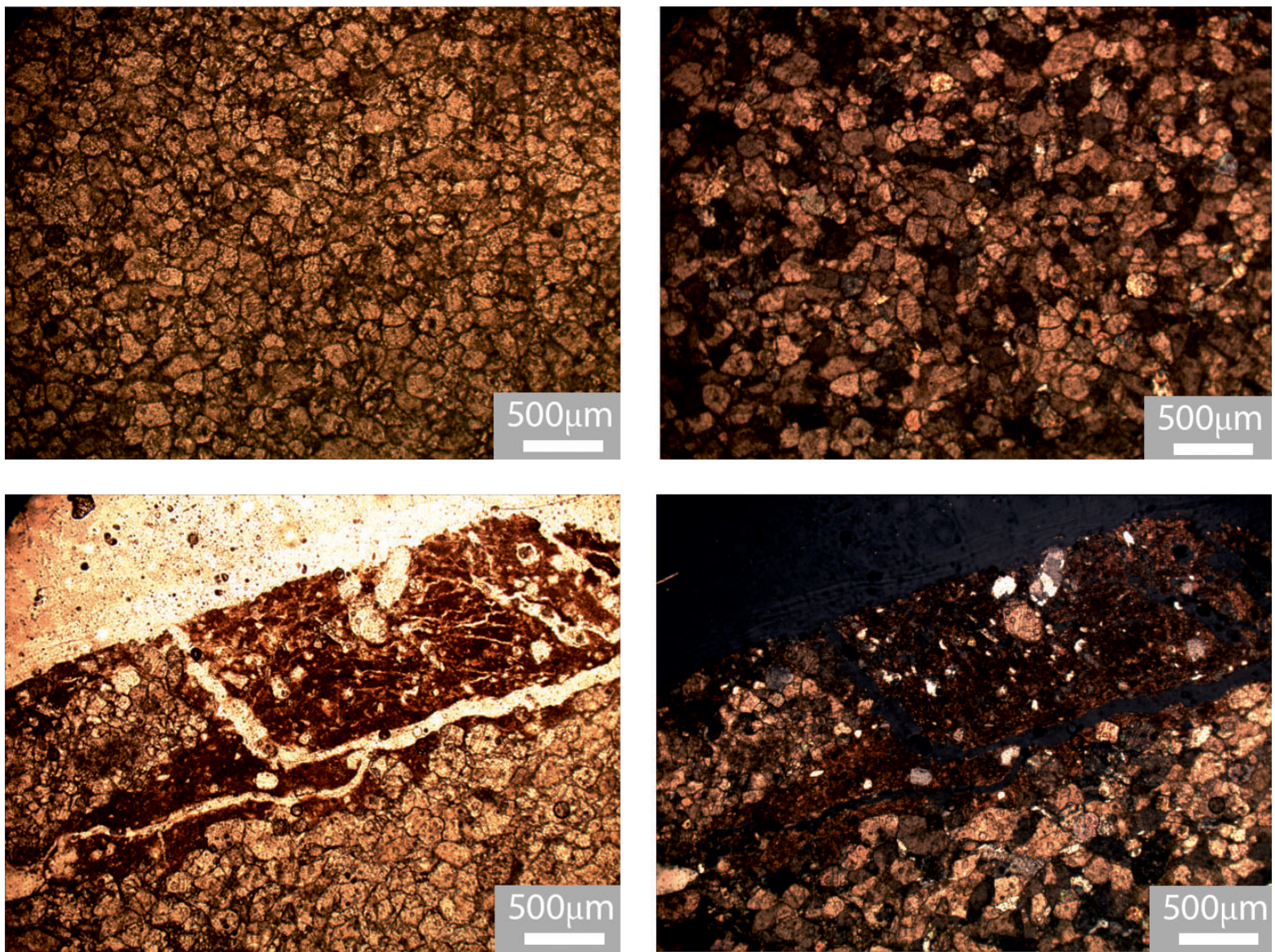

Figure 12. Detail of vugs cemented by equigranular sparitic calcite related to microcodium structures.

\subsection{Raw materials and knapping sequences}

The petrographic analysis of the Picamoixons assemblage indicates that Tossa chert was the main type exploited ( $\mathrm{n}=141,43 \%)$, versus the Lutetian (Morera, Maset and Vilella) $(n=125,38 \%)$ and Triassic (Upper and Lower Muschelkalk) $(n=12,4 \%)$ cherts (Figure 13).

$14 \%$ of the archaeological assemblage presents cortical surfaces, and therefore could be associated to the first knapping episodes.

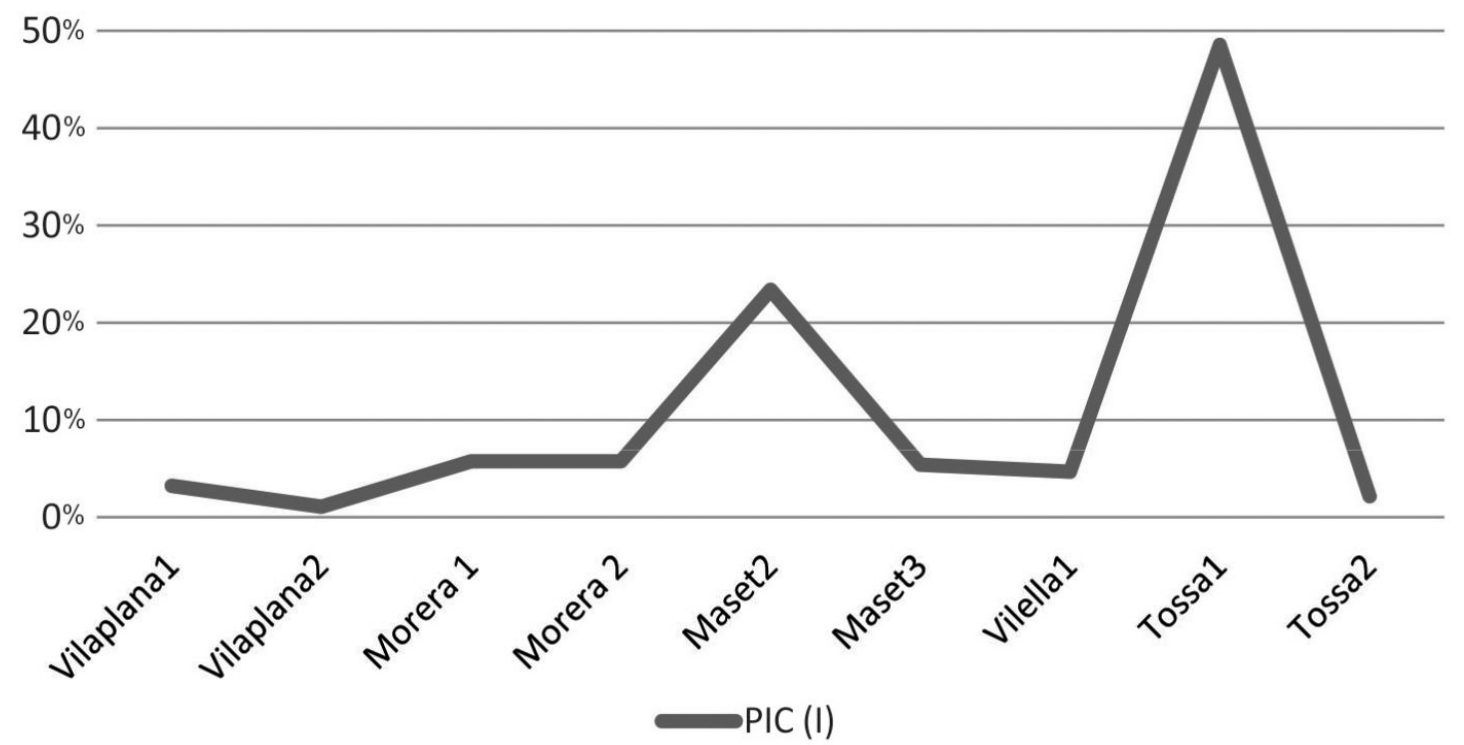

Figure 13. Distribution of the chert varieties identified in the Picamoixons assemblage. 
An association of the chert-types to the different structural categories points to the Tossa 1 and Maset 2 as being the most exploited and the only chert varieties seen in each category (Table 3).

Table 3. Chert type distribution according to the structural categories of the knapping sequence.

\begin{tabular}{|c|c|c|c|c|c|c|c|c|}
\hline & $\frac{\frac{y}{0}}{0}$ & $\frac{\mathscr{d}}{\frac{\pi}{\pi}}$ & 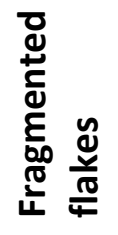 & 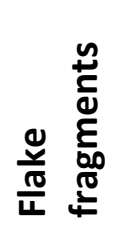 & dँ & 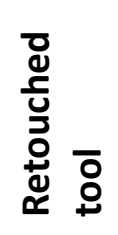 & 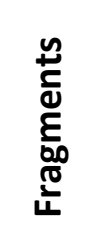 & $\begin{array}{l}\bar{\pi} \\
\stackrel{0}{\circ} \\
\text { o }\end{array}$ \\
\hline Vilaplana 1 & & 6 & 1 & 1 & & 1 & & 9 \\
\hline Vilaplana 2 & & 2 & & & & 1 & & 3 \\
\hline Morera 1 & 1 & 7 & 2 & & & 5 & 1 & 16 \\
\hline Morera 2 & & 5 & 2 & 2 & 5 & & 2 & 16 \\
\hline Maset 2 & & 37 & 9 & 11 & 2 & 1 & 5 & 65 \\
\hline Maset 3 & & 3 & 4 & 2 & & 6 & & 15 \\
\hline Vilella 1 & & 4 & 2 & 4 & & 1 & 2 & 13 \\
\hline Tossa 1 & 2 & 56 & 11 & 28 & 5 & 14 & 19 & 135 \\
\hline Tossa 2 & & 2 & 1 & 1 & & & 2 & 6 \\
\hline
\end{tabular}

The analysis (Table 4) shows a homogeneous distribution for the Tossa 1 type refuting the existence of differential exploitation strategies for this chert. On the other hand, the results for the Maset 2 variety indicatean overrepresentation flakes and a lower number of retouched elements with regard to the expected values.

The absence of cores in most of the raw materials defined does not provide significant values in the distribution test, but justifies the overrepresentation of the retouched tools of Morera 1 and Maset 3 varieties. The absence of retouched tools of Morera 2 also causes the significant overrepresentation of cores.

The chi-square test indicates the existence of differential management strategies for the Maset and Morera cherts, proposing the selection of certain varieties for the retouched tools. In other cases, a significant absence in the assemblage, suggests their transport or disposal away from the site.

The low number of remains associated to the Vilaplana, Vilella and Tossa 2 varieties, and their classification as knapping products, suggests they were exploited sporadically and opportunistically.

\section{Discussion}

The petrographic analysis of the chert varieties defined in the assemblage of Picamoixons site determines the potential procurement of the Vilaplana chert from the outcrops located in the Francolí and Siurana basin. The procurement of Morera, Maset and Vilella siliceous rocks types is related to the outcrops sampled around the Siurana, Montsant and Francolí basins, and the procurement of Tossa cherts is established as being from the upper and middle Francolí river basin.

The definition of these provenances suggests a mobility radius between 3 and $25 \mathrm{~km}$ for the Vilaplana cherts; between 27 and $30 \mathrm{~km}$ for evaporitic varieties (Morera, Maset and Vilella types); and distances of 3-7 km for the procurement of Tossa chert. 
Table 4. Chi-square results presented in two columns: 1. Lithic remains described; 2. a) Heterogeneity sign according to the expected value: (+) overrepresented or (-) underrepresented in the assemblage. b) Statistical probability. c) Chi-square value. Abbreviations: AT.Altered types; Vil..Vilaplana; Mor. Morera; Mas. Maset; Vile. Vilella;

Tos. Tossa (Rows). Cob. Cobbles; Fl. Flake; FFl. Fragmented Flake; FlF. Flake Fragment; Ret. Retouched tool: Frag. Fragments (Columns).

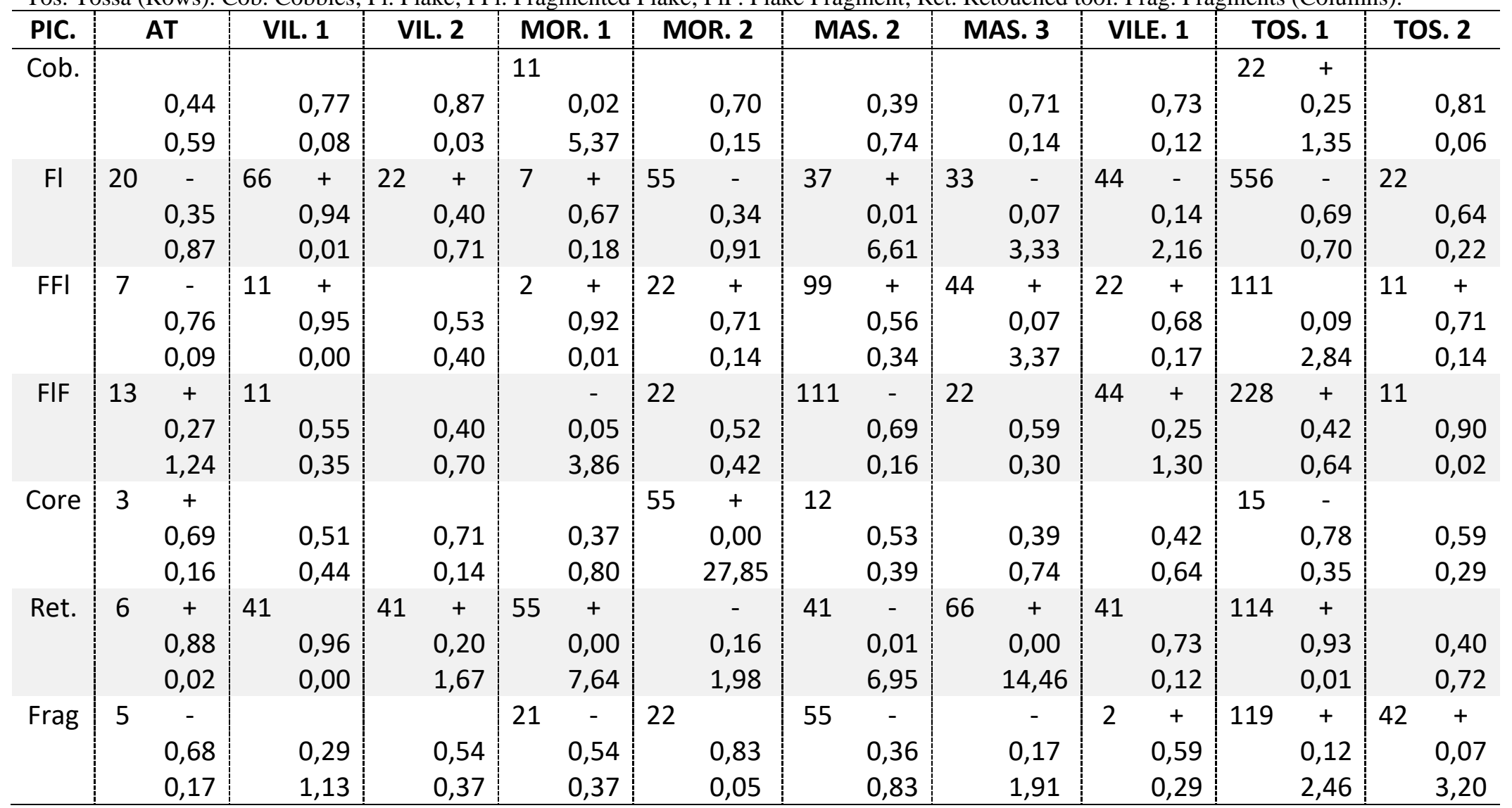


The areas of least displacement cost indicate the importance of the fluvial basins as natural pathways. The middle basin of the Francolí River is the access route to the outcrops located around, and the upper basins of the Francolí and Montsant are the most important areas for procurement in the western sector of the prospected area (Figure 14).

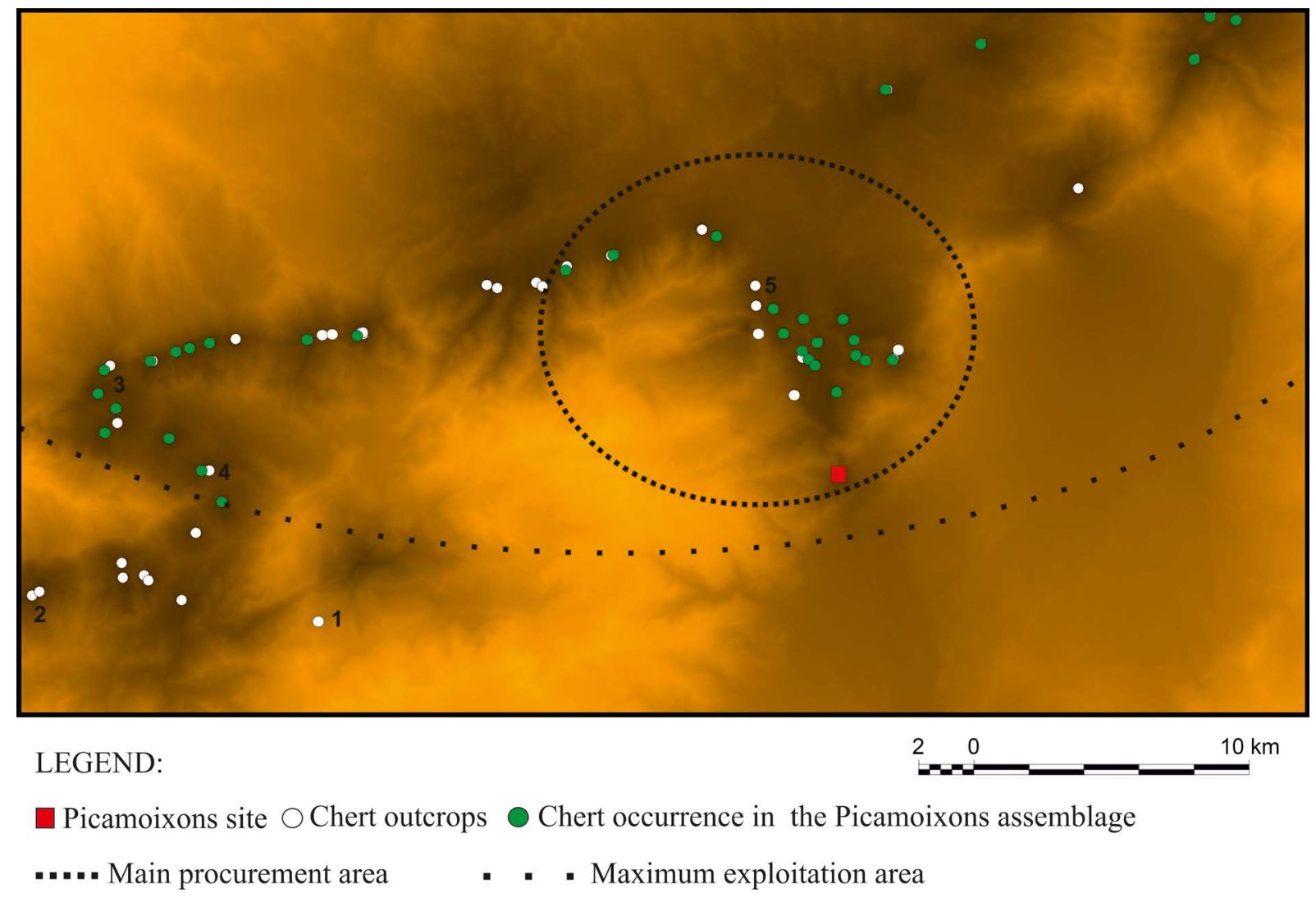

Figure 14. Map of the areas with lowest displacement cost marked in blackish colours.

The definition of this procurement area suggests an exploited territory of around $16 \mathrm{~km}^{2}$, including the mobility axes in an immediate-local range, associable with a forager radius. The most remote procurement distances suggest a maximum exploitation territory of $260 \mathrm{~km}^{2}$, which is therefore defined as an intra-regional range (Féblot-Augustins 2009).

The intra-regional range displays similarities with those of other Late Pleistocene-Early Holocene groups in Western Europe (Aubry 1991; Aubry et al. 2003; Langlais 2007; Mangado 2002; Sánchez de la Torre 2015), where long procurement distances and allochtonous materials were common during the early Upper Paleolithic (e.g., Bordes et al. 2005; Primault 2003; Renard 2008; Séronie-Vivien et al. 2006).

This long-distance tendency seemed to be reversed during Magdalenian, due to a decrease in procurement distances. Some authors explain this tendency by the standardization of knapping strategies, a potential demographic increase or the combination of both factors, as well as other possibilities (Brown \& Douglas Price 1985; Kelly 1992).

During Late Magdalenian the average maximum procurement distances decreased to $170 \mathrm{~km}$ in southwestern Germany (Burkert \& Floss 2005) to $190 \mathrm{~km}$ in Central and Southern France (e.g., (Surmely \& Pasty 2003), and between 200-270 km for the Pyrenean region, the Basque Country (Langlais 2007; Sánchez de la Torre 2015), and the Cantabrian area (Corchón 2012; García Moreno 2010; González Sainz 1992).

This reduction is still more visible in the Catalonian and Portuguese sites (e.g., (Bicho 2002; Bicho et al. 2009; Fullola et al. 2006; Terrades 1992) during Late Magdalenian and 
Mesolithic periods, where lithic provenance studies indicate the dominance of local materials, with maximum procurement distances being around $50 \mathrm{~km}$.

The CIIA lithic assemblage at Picamoixons could be part of this progressive mobility reduction dynamic. In this particular case, the short-distances travelled could also be the consequence of the high resource availability and accessibility of resources, making the study area a territory with high raw material predictability. This scenario suggests a model where continuous provisioning is possible, allowing a high level of regional mobility that progressively led to reduced mobility in the last hunter-gatherer groups (Kelly 1992).

\section{Conclusions}

The main points that can be drawn from study of the lithic raw materials from the CIIA level of the Picamoixons site are:

- Nine macroscopic chert varieties were exploited related to five siliceous rock types described from around the Montsant, Prades and Miramar ranges.

- Bartonian chert originated in carbonate lacustrine deposits (Tossa type), was predominantly used.

- There are complete in-situ knapping sequences of the most-commonly represented lithic supports.

- There were differential management strategies related to the Lutetian evaporitic cherts.

- The outcrops located in the middle Francolí basin, and in the head of the Montsant and Siurana basins are the potential procurement areas, suggesting a catchment model based on the frequentation of high availability areas.

- The circulation axes show a NNW direction, in line with the fluvial basins, and the areas of least displacement cost.

- The potential procurement areas suggest an exploitation area coinciding with a forager radius.

\section{Acknowledgements}

This research has been supported by Generalitat de Catalunya, Archaeological and Palaeontological Quadrennial projects 2014/100574, 2014/100482 and 2014-SGR-901, and by the Spanish Ministerio de Economía y Competitividad projects HAR2013-41197-P and CGL 2015-65387-C3-1-P (MINECO/FEDER). The author also wants to express her gratitude to Josep Vallverdú, Juan Ignacio Morales and Bruno Gómez de Soler for their constructive critiques of previous drafts.

\section{References}

Angelucci, D.E. 2005, Nuevas aportaciones sobre el límite Pleistoceno-Holoceno en Cataluña: Los yacimientos del Abric de la Cativera y de Picamoixons (Tarragona). In: Geoarqueología y Patrimonio en la Península Ibérica y el entorno mediterráneo (Santonja, M., Pérez-González, A. \& Machado, M.J., Eds.), Adema, Soria: p. 395-409. (in Spanish) ("New contributions to the Pleistocene-Holocene boundary in Catalonia: The Cativera rockshelter and Picamoixons sites (Tarragona)”)

Arbey, F. 1980, Les formes de la silice et l'identification des evaporites dans les formations silicifiees. Bulletin des Centres de Recherches Exploration-Production Elf-Aquitaine, 4: 309-365. (in French) ("Silica forms and evaporites identification in silicified formations") 
Aubry, T. 1991, L'explotation des ressources en matières premières lithiques dans les gisements solutreens et badegouliens du Bassin Versant de la Creuse (France). Doctoral thesis at Université Bourdeaux I, Bourdeaux, 326 p. (in French) ("The lithic raw materials exploitation in the solutrean and badegoulian sites of Versant de la Creuse basin (France)”)

Aubry, T., Chauvière, F.-X., Mangado LLach, X. \& Sampaio, J.D. 2003, Constitution, Territoires d'approvisionnement et fonction des sites du Paleolithique Superieur de la Basse Vallée du Coâ (Portugal). In: Perceived Landscapes and Built Environments. The cultural geography of Late Palaeolithic Eurasia (Vasil'ev; S.A, S.O., Kowlozski, W, Ed.) BAR international Series Vol. 1122, Archeopress, Oxford: p. 83-92. (in French) ("Setting up, catchment territories and functionalities of Upper Palaeolithic sites from Lower Coa Valley (Portugal)”)

Bathrust, R.G. 1975, Carbonates Sediments and their diagenesis. Developments in Sedimentology Vol. 12. Elsevier, Amsterdam, 658 p.

Bicho, N.F. 2002, Lithic Raw Material Economy and Hunter-Gatherer Mobility in the Late Glacial and Early Postglacial in Portuguese Prehistory. In: Lithic raw material economies in late glacial and early postglacial Europe (Fisher, L.E. \& Eriksen, B.V., Eds.), BAR International Series Vol. 1093, Archeopress, Oxford: p. 161-179.

Bicho, N.F., Haws, J., Gibaja, J.F. \& Hockett, B. 2009, Lapa do Picareiro, un asentamiento de caza magdaleniense en la Estremadura portuguesa. Complutum, 20(1): 71-82. (in Spanish) ("Lapa do Picareiro, a magdalenian hunting camp in the portuguese Estremadura”)

URL: http://revistas.ucm.es/index.php/CMPL/article/view/CMPL0909120071A

Binford, L.R. 1983, Long-term land-use patterning: Some implications for archaeology. In: Working at Archaeology (Binford, L.R.), Academic Press, New York: p. 379-386.

Boggs, J., S. 2009, Petrology of sedimentary rocks (2nd ed.). Cambridge University Press, Cambridge, $600 \mathrm{p}$.

Bordes, J.G., Bon, F. \& Le Brun-Ricalens, F. 2005, Le transport des matières premières lithiques à l'Aurignacien entre le nord et le sud de l'Aquitaine: Faits attendus, faits nouveaux. In: Territoires, déplacements, mobilité, échanges durant la Préhistoire: Terres et hommes du sud (Jaubert, J. \& Barbaza, M., Eds.), Actes des congrès nationaux des sociétés historiques et scientifiques Vol. 126, Comité des Travaux Historiques et Scientifiques (CTHS), Paris: p. 185-198. (in French) ("Lithic raw materials transport during Aurignacian between northern and southern Aquitaine: Expected facts, new facts”)

Brannan, J.A. 1992, On modeling resource transport costs: Suggested refinements. Current Anthropology, 33(1): 56-60. URL: http://www.jstor.org/stable/2743710

Brown, J.A. \& Douglas Price, T. 1985, Complex Hunter-Gatherers: Retrospect and Prospect. In: Prehistoric Hunter-Gatherers. The Emergence of Cultural Complexity (Douglas Price, T., Brown, J.A., Ed.), Academic Press, London p. 435-442.

Burkert, W. \& Floss, H. 2005, Lithic Exploitation Areas in the Upper Paleolithic of West and Southwest Germany - A Comparative Study. In: Stone Age - Mining Age. Proceedings VIII. Flint Symposium, Bochum, 13.-17.9.1999 Vol. 19 (Körlin, G. \& Weisgerber, G., Eds.), Der Anschnitt; Montanhistorische Zeitschrift Vol. 19, Deutsches BergbauMuseum Bochum, Bochum: p. 35-49. 
Carbonell, E., Borrego, A.M., Diloli, J., Esteban, M., Foguet, G., Gabarró, J.M., Hortolá, P., Juárez, P., Lorenzo, C., Ollé, A., Perales, C., Prats, J.M., Rodríguez, X.P., Rodríguez, A., Rosell, J., Salvadó, M., Vaquero, M. \& Vergés, J.M. 1989, El centre d’intervenció prehistòrica de Picamoixons. Butlletí Arqueològic, 8-9: 3-14. (in Catalan) ("The prehistoric intervention center of Picamoixons”)

Collinson, J.D., Mountney, N.P. \& Thompson, D.B. 2006, Depositional structures of chemical and biological origin. Chapter 8. In: Sedimentary structures (Collinson, J.D., Mountney, N.P. \& Thompson, D.B., Eds.), Terra Publishing, Hertfordshire: p. 292.

Corchón, M.S. 2012, Gestión del territorio y movilidad de los grupos cazadores-recolectores del valle del Nalón (Asturias, España) durante el Tardiglacial. In: El Paleolítico Superior Cantábrico: Actas de la Primera Mesa Redonda, San Román de Candamo (Asturias), 26-28 de abril de 2007 (Cabal, P.A., Rodríguez, S.C., Fernández, M.M. \& Asensio, J.A.R., Eds.), Monografías del Instituto Internacional de Investigaciones Prehistóricas de Cantabria Vol. 3, PubliCan; Universidad de Cantabria, Santander: p. 21-48. (in Spanish) ("Territorial management and mobility of hunter-gatherers groups in the Nalón valley (Asturias, Spain) during Late Glacial”)

Dunham, R.J. 1962, Classification of Carbonate Rocks According to Depositional Texture. In: Classification of Carbonate Rocks, A Symposium (Hamm, W.E., Ed.), American Association of Petroleum Geologists, Tulsa: p. 108-121.

Dyson-Hudson, R., Alden Smith, E. 1978, Human territoriality: An ecological reassessment. American Anthropologist, 80(1): 21-41. doi:10.1525/aa.1978.80.1.02a00020

Elston, R.G. 1992, Modeling the economics and organization of lithic procurement. In: Archaeological Investigations at Tosawihi, A Great Basin Quarry, Part 1: The periphery (Elston, R. G., and Raven, C., Eds.), Report prepared for the Bureau of Land Management, Elko Resource Area, Silver City, Nevada, 31-47 p.

Féblot-Augustins, J. 2009, Revisiting European Upper Paleolithic raw materials transfers: The demise of th cultural ecological paradigm? In: Lithic Materials and Paleolithic Societies (Adams, B. \& Blades, B.S., Eds.), Blackwell Publishing Ltd., Chichester: p. 25-46. doi:10.1002/9781444311976.ch3

Fernandes, P. 2012, Itinéraires et transformations du silex: Une pétroarchéologie refondée, application au Paléolithique moyen. Doctoral thesis at the École Doctorale Sciences et Environnement, L'Université de Bordeaux I, Bordeaux, 623 p. (in French) (“Itineraries and transformations of chert: A renovated petroarchaeology. Application to the Middle Palaeolithic") URL: http://ori-oai.ubordeaux1.fr/pdf/2012/FERNANDES_PAUL_2012.pdf

Folk, R.L. 1959, Practical petrographic classification of limestones. American Association of Petroleum Geologists Bulletin, 43: 1-38.

Fullola, J.M., Mangado, X., Estrada, A. \& Nadal, J. 2006, Comunidades humanas y circulación de recursos, bióticos y abióticos, en el Paleolítico Superior del Noreste de la Península Ibérica. Zephyrus, 59: 89-96. (in Spanish) ("Human communities and circulation biotic and abiotic resources during the Upper Palaeolithic in the Northeast of Iberian Peninsula”) URL: http://campus.usal.es/ revistas_trabajo/index.php/05147336/article/viewFile/5641/ 
García Catalán, S., Vaquero Rodríguez, M., Pérez Goñi, I., Menéndez Iglesias, L., Peña García, L., Blasco López, R., Mancha Flores, E., Moreno García, D. \& Muñoz Encinar, L. 2009, Palimpsestos y cambios culturales en el límite Pleistoceno-Holoceno: El conjunto lítico de Picamoixons (Alt Camp, Tarragona). Trabajos de Prehistoria, 66(1): 61-76. (in Spanish) ("Palimpsests and cultural changes in the Pleistocene- Holocene boundary: The lithic assemblage from Picamoixons (Alt Camp, Tarragona)”) doi:10.3989/tp.2009.0919

García Moreno, A. 2010, Patrones de asentamiento y ocupación del territorio en el Cantábrico Oriental al final del Pleistoceno.Una aproximación mediante SIG. Doctoral thesis at the Facultad de Filosofía y Letras, Departamento de Ciencias Históricas, Universidad de Cantabria, Santander, 427 p. (in Spanish) (“Settlement patterns and territorial occupation in the Eastern Cantabrian during Final Pleistocene. A GIS approach”) URL: https://repositorio.unican.es/xmlui/handle/10902/2315

González Sainz, C. 1992, Aproximación al aprovechamiento económico de las poblaciones cantábricas durante el Tardiglacial. In: Elefantes, ciervos y ovicaprinos: Economía y aprovechamiento del medio en la Prehistoria de España y Portugal (Romanillo, A.M., Ed.), Universidad de Cantabria, Santander: p. 129-147. (in Spanish) (“Approach to the economic exploitation of cantabric populations during Late Glacial. Elephants, derrs and ovicaprine: Economy and environmental during Prehistory in Spain and Portugal”)

Grove, M. 2009, Hunter-gatherer movement patterns: Causes and constrains. Journal of Anthropological Archaeology, 28: 222-233. doi:10.1016/j.jaa.2009.01.003

Grove, M. 2010, Logistical mobility reduces subsistence risk in hunting economies. Journal of Archaeological Science, 37: 1913-1921. doi:10.1016/j.jas.2010.02.017

Hodder, I. \& Orton, C. 1976, Spatial Analysis in Archaeology. New studies in archaeology Vol. 1. Cambridge University Press, Cambridge, 270 p.

Humbert, L. 1976, Éléments de pétrologie dynamique des systèmes calcaires. Vol. 1. Description macroscopique et microscopique. Diagènese, Applications. Editions Technip, Paris, 213 p. (in French) ("Elements from dynamic petrology of the calcareous systems. Macroscopic and microscopic description. Diagenesis, applications”)

Kelly, R.L. 1992, Mobility/sedentism: Concepts, archaeological measures, and effects. Annual Review of Anthropology, 21(43-66). doi:10.1146/annurev.an.21.100192.000355

Kendall, A.C. 1979, Facies Models 12. Subacqueous evaporites. Geoscience Canada, 5(3): 124-139.

Langlais, M. 2007, Dynamiques culturelles des sociétés magdaléniennes dans leurs cadres environnementaux: Enquête sur 7000 ans d'évolution de leurs industries lithiques entre Rhône et Ebre. Doctoral thesis at Université de Toulouse - Le Mirail (Toulouse 2), Toulouse, 548 p. (in French) ("Cultural dynamics of the Magdalenian societies within their environmental framework: Research about 7000 years of lithic assemblages evolution between Rhône and Ebro") URL: www.these.fr/2007TOU20075

Mangado, X. 2002, El aprovisonamiento de materias primas líticas durante el Paleolítico superior y el Epipaleolítico de Cataluña. Cypsela, 14: 27-41. (in Spanish) ("The lithic raw material procurement during Upper Palaeolithic and Epipalaeolithic in Catalonia”) URL: http://www.raco.cat/index.php/Cypsela/article/view/112481 
Mangado, X. 2004, L'arqueopetrologia del sílex. una clau per al coneixement paleoeconòmic i social de les poblacions prehistòriques. Premi d'arqueologia. Memorial Josep Barberà i Farràs. Societat Catalana d'Arqueologia, Barcelona, 116 p.

Morales, J.I., Burjachs, F., Allué, E., Fontanals, M., Soto, M., Expósito, I., Gassiot, E., Pèlachs, A., Pérez-Obiols, R., Soriano, J.M., Vergès, J.M. \& Yll, E. 2012, Paleogeografía humana durante el Tardiglaciar y Holoceno inicial en el ámbito mediterráneo del NE Ibérico. Cuaternario y Geomorfología, 26(3-4): 11-28. (in Spanish) ("Human palaeogeography during the Tardiglaciar and initial Holocene in the Mediterranean area of the Iberian NE”)

Ortí, F., Rosell, L., Playà, E., Salvany, J. M. 2012, Meganodular anhydritization: A new mechanism of gypsum to anhydrite conversion (Palaeogene-Neogene, Ebro Basin, North-east Spain). Sedimentology, 59(4): 1257-1277. URL: 10.1111/j.13653091.2011.01305.x

Primault, J. 2003, Exploitation et diffusion des silex de la région du Grand-Pressigny au Paléolithique. Doctoral thesis at the U.F.R. des Sciences Sociales et Administratives, Université de Paris X-Nanterre, Paris, 362 p. (in French) ("Exploitation and diffusion of the flynt from Grand-Pressigny region during Palaeolithic”) URL: https://tel.archivesouvertes.fr/tel-00132540/

Renard, C. 2008, Les premières expressions du Solutréen dans le Sud-Ouest français: Évolution techno-économique des équipements lithiques au cours du Dernier Maximum Glaciaire. Doctoral thesis at Université Paris Ouest Nanterre La Défense, Nanterre, 448 p. (in French) ("The first Solutrean expressions in the southwestern France: Technoeconomic evolution of the lithic assemblages druing the Last Maximum Glacial”) URL: www.theses.fr/2008PA100173

Sánchez de la Torre, M. 2015, Las sociedades cazadoras-recolectoras del Paleolítico superior final pirenaico: Territorios económicos y sociales. Monografies del SERP Vol. 11. Seminari d'Estudis i Recerques Prehistòriques, Barcelona, 314 p. (in Spanish) ("Hunter-gatherer societies of the Final Upper Palaeolithic: Economic and social territories”)

Schmalz, R.F. 1960, Flint and Patination of Flint Artifacts. The Prehistoric Society, 26: 44-49.

Séronie-Vivien, M., Séronie-Vivien, M.R. \& Foucher, P. 2006, L’économie du silex au Paléolithique supérieur dans le bassin d'Aquitaine. Le cas des silex à lépidorbitoïdes des Pyrénées centrales. Caractérisation et implications méthodologiques. PALEO. Revue d'archéologie préhistorique, 18: 193-216. (in French) ("Flynt economy during Upper Palaeolithic in the Aquitanie bassin. The case of flynt with lepidorbitoids in the Central Pyrenees. Caractherisation and methodological implications”)

URL: http://paleo.revues.org/316

Sonnefeld, P. 1979, Brines and evaporites. Geoscience Canada, 6(2): 83-90. URL: https://journals.lib.unb.ca/index.php/GC/article/viewArticle/3157

Soto, M. 2015, Áreas y estrategias de aprovisionamiento lítico de los últimos cazadoresrecolectores en las Montañas de Prades (Tarragona). Doctoral thesis no. T 230-2016 at the Departamento de Història i Història de l'Art, Universitat Rovira i Virgili, Tarragona, 715 p. (in Spanish) (“ Areas and lithic procurement strategies among the last huntergatherers in the Prades range (Tarragona)")

URL: http://www.tdx.cat/handle/10803/348554 
Stoops, G. 2003, Guidelines for Analysis and Description of Soil and Regolith Thin sections. Soil Science Society of America, Madison (Wisconsin), $184 \mathrm{p}$.

Surmely, F. \& Pasty, J.F. 2003, L’importation de silex en Auvergne durant la Préhistoire. In: Actes de la Table ronde internationale d'Aurillac «les matières premières lithiques en préhistoire: p. 327-336. (in French) ("Flynt importation in Auvergne during Prehistory")

Tarriño, A. 2006, El sílex en la Cuenca Vasco-Cantábrica y Pirineo navarro. Caracterización y su aprovechamiento en la prehistoria. Monografías Vol. 21. Museo Nacional y Centro de Investigación de Altamira, Altamira, 263 p. (in Spanish) (“Chert from VascoCantabrian Basin and Navarrean Pyrenees”)

Terrades, X., Mora, R., Plana, C., Parpal, A. \& Martínez, J. 1992, Estudio preliminar de las ocupaciones del yacimiento al aire libre de la Font del Ros (Berga, Barcelona). In: Arágon/Litoral Mediterráneo. Intercambios culturales durante la Prehistoria. En homenaje a Juan Maluquer de Motes (Miranda, P.U., Ed.), Institución Fernando el Católico, Zaragoza: p. 285-296. (in Spanish) ("Preliminary study of the occupations in the Font del Ros open-air site (Berga, Barcelona)”)

Tucker, M. \& Wright, P. 1990, Carbonate depositional systems I: Marine shallow-water and lacustrine carbonates. In: Carbonate Sedimentology (Tucker, M. \& Wright, P., Eds.), Blakwell Science, Oxford: p. 101-227. doi:10.1002/9781444314175.ch4

Vallverdú, J. 1994, Memòria d'intervenció d'urgència. Picamoixons Y-Y'93 (Valls, Alt Camp). (unpublished report), Departament de Cultura, Generalitat de Catalunya. Laboratori d'arqueologia de la Universitat Rovira i Virgili, Tarragona, 110 p. (in Catalan) (“Rescue Intervention Report. Picamoixons Y-Y'93 (Valls, Alt Camp)”)

Vera, J.A. \& Molina, J.M. 2001, Liesengang rings in pelagic limestones: Genetic considerations. Geogaceta, 29: 151-154.

URL: http://www.sociedadgeologica.es/archivos/geogacetas/Geo29/Art40.pdf

Vergés, J.M. 1989, Picamoixons: Assentament d'un poblat de caça i recol-lecció a la vora del Riu Francolí. Recerca: 163-171. (in Catalan) ("Picamoixons: A settlement of huntergatherers next to a river bank”)

Warren, J.K. 2010, Evaporites through time: Tectonic, climatic and eustatic controls in marine and nonmarine deposits. Earth-Science Reviews, 98 (3-4): 217-268. doi:10.1016/j.earscirev.2009.11.004

Wobst, H.M. 1974, Boundary conditions for Paleolithic social systems: A simulation Approach. American Antiquity, 39(2): 147-178. doi:10.2307/279579 


\title{
Aprovisionamiento y movilidad durante el Pleistoceno final: Caracterización del conjunto lítico de Picamoixons (Tarragona, NE Península Ibérica)
}

\author{
María Soto \\ Institut Català de Paleoecologia Humana i Evolució Social (IPHES). C/Marcel.lí Domingo s/n (Edifici W3), \\ Campus Sescelades, 43007, Tarragona, España. y Àrea de Prehistoria, Universitat Rovira i Virgili (URV), \\ Avinguda Catalunya, 35, 43002, Tarragona, España. Email: sotoquesadamaria@gmail.com
}

\section{Resumen:}

El yacimiento de Picamoixons se localiza en la provincia de Tarragona (NE de la Península Ibérica). El abrigo fue objeto de dos intervenciones de urgencia durante 1988 y 1993, que permitieron recuperar abundante material arqueológico, incluyendo industria lítica, fauna y objetos de arte mueble, que permitieron datar su ocupación ente el XIV-XI mil cal BP.

Este estudio supone la caracterización petrográfica del conjunto lítico recuperado, con los objetivos de establecer: 1) las áreas de aprovisionamiento; 2) las estrategias de gestión de las materias primas y 3) la definición de los radios de movilidad y los tamaños territoriales de los grupos de cazadores-recolectores que ocuparon el yacimiento. La metodología aplicada consiste en un análisis multi-escalar que incluye: prospecciones sistemáticas, la caracterización petrográfica de las muestras tanto geológicas como arqueológicas, el análisis de la representación de los tipos silíceos en la cadena operativa y la definición de los ejes de movilidad y las áreas de frecuentación según el aprovisionamiento lítico.

Los análisis petrográficos permitieron identificar nueve variedades macroscópicas asociadas a cinco tipos silíceos (Vilaplana, Morera, Maset, Vilella y Tossa) identificados en el área prospectada y asociados a depósitos datados en el Muschelkalk inferior y superior (Triásico), Luteciense, Bartoniense (Paleoceno) y Sanoniense (Oligoceno).El estudio de las secuencias de talla indican la explotación dominante de los sílex bartonienses (tipo Tossa) y proponen estrategias de gestión diferencial de los sílex lutecienses (tipo Maset y Morera) para configurar instrumentos retocados. La explotación del resto de materias primas identificadas se considera esporádica y oportunista. La definición de las áreas de aprovisionamiento propone radios de movilidad entre 3 y $30 \mathrm{~km}$, subrayando la importancia de las cuencas fluviales como vías naturales para la circulación. Los resultados indican que el territorio de explotación dominante ocupa un área en torno a los $16 \mathrm{~km}^{2}$, asociables con el radio de forrajeo. Las mayores distancias de aprovisionamiento sugieren un territorio de aprovisionamiento máximo de unos $260 \mathrm{~km}^{2}$, definiendo un rango intra-regional. Este rango presenta paralelismos con diferentes grupos de cazadores-recolectores contemporáneos en Europa occidental, sugiriendo una dinámica de progresiva reducción de la movilidad durante el Pleistoceno final-Holoceno inicial.

Palabras clave: Pleistoceno final; Holoceno inicial; sílex; petrografía; aprovisionamiento; movilidad 